\title{
The Glorifications of Herisenef in the Museo Egizio (P. Turin Cat. 2117 (R 08))
}

\author{
Ann-Katrin Gill
}

This paper publishes for the first time and discusses P. Turin Cat. 2117 (R 08). The owner of the manuscript is identified and information regarding his family and career collected and analysed. This is followed by a presentation of parallels for the texts, a discussion of the layout and palaeography of the manuscript, a hieroglyphic transcription, and a transliteration and translation, as well as a commentary on the general content and on specific textual passages. The paper is concluded by an investigation of the specific combination of spells that Herisenef chose for his funerary papyrus.

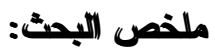

تُشر هذه الدراسة لأول مرة وتناقش بردية رقم P. Turin Cat. 2117 (R 08) بالمتحف المصري بتورينو، تم التعرف على صاحب هذه المخطوطة، كما تم جمع المعلومات المتعلقة بعائلته وبحياته المهنية وتحليلها. يتبع ذلك عرض للنصوص ومناقشة تصميم المخطوطة ودراستها من خلال علم المخطوطات وكتابتها الهيروغليفية ونقل لفظها وترجمتها بالإضافة إلى التعليق على المحتوى بشكل عام وعلى مقاطع نصية محددة. إختُمت الدراسة ببحث مجموعة محددة من التعاويذ التي إختارها "حِري-سنف" روتر

\section{Introduction and physical description}

The papyrus roll, bearing the inventory number Cat. 2117 (R 08) in the Museo Egizio, was first described in the catalogue by Fabretti, Rossi, and Lanzone in 1882: "Rotolo di papiro con testo jeratico alto $\mathrm{m}$. 0,27 , tutto rotto e guasto dal bitumen, segnato col $n$. VIII". Apart from this, no further information about this papyrus is provided in the museum records, and it has not received any attention in Egyptological literature since. The manuscript was most likely acquired by the museum in 1824 as part of the Drovetti collection. Even though no records concerning its acquisition or provenance exist, the following investigation of its owner will show that Thebes is a highly likely place of origin. Furthermore, it will show that the papyrus is not as "tutto rotto" as Fabretti et al. assumed. ${ }^{2}$

In its current state, the papyrus roll (Fig. 1, Pls. 1-3) is $26.4 \mathrm{~cm}$ high and $46 \mathrm{~cm}$ long, and is of a light brown colour. Several bitumen stains are visible along the upper margin of the recto and in a number of areas on the verso, especially of the first sheet. Three sheet joins are still preserved (the first after $1.5 \mathrm{~cm}$ from the right side on the recto, the second after an additional $15 \mathrm{~cm}$, and the third after an additional $14.5 \mathrm{~cm}$ ), as well as the verso fibres that were usually attached to the recto in order to mark the end of a papyrus roll. ${ }^{3}$ The scribe used the sheet joins as a reference for drawing the black double lines that separate the columns.

Two strips of linen with traces of bitumen are still attached to the verso (Fig. 2). According to information previously in the main database of the Museo Egizio, these were used to close the rolled-up papyrus manuscript. However, it is obvious that the scribe removed a strip of the papyrus layer from the verso - approximately in the middle of the roll -, which he most likely rolled into a cord-like shape and used 


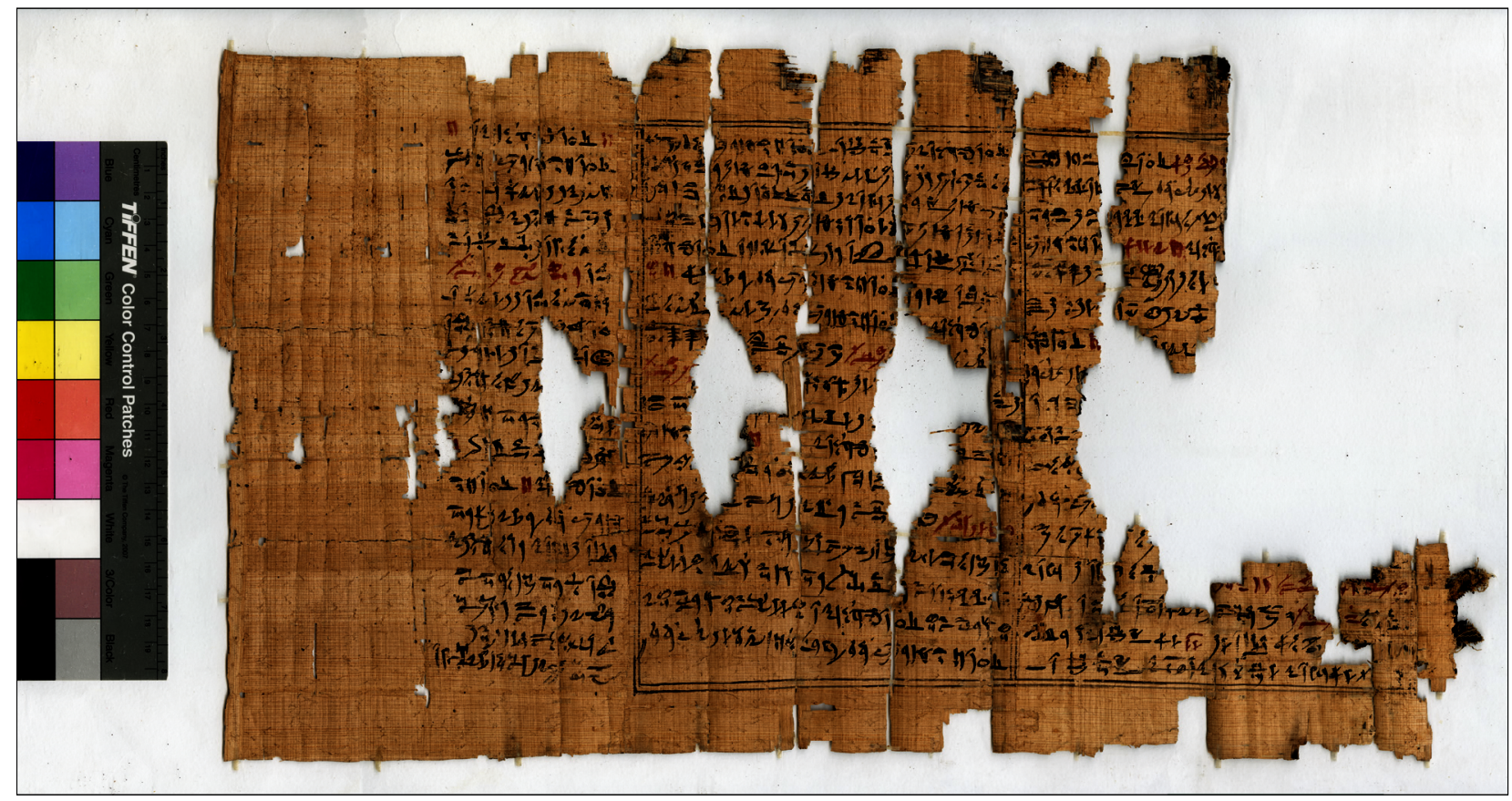

Fig. 1: P. Turin Cat. 2117 (R 08), recto, as currently mounted. Scan by Museo Egizio.

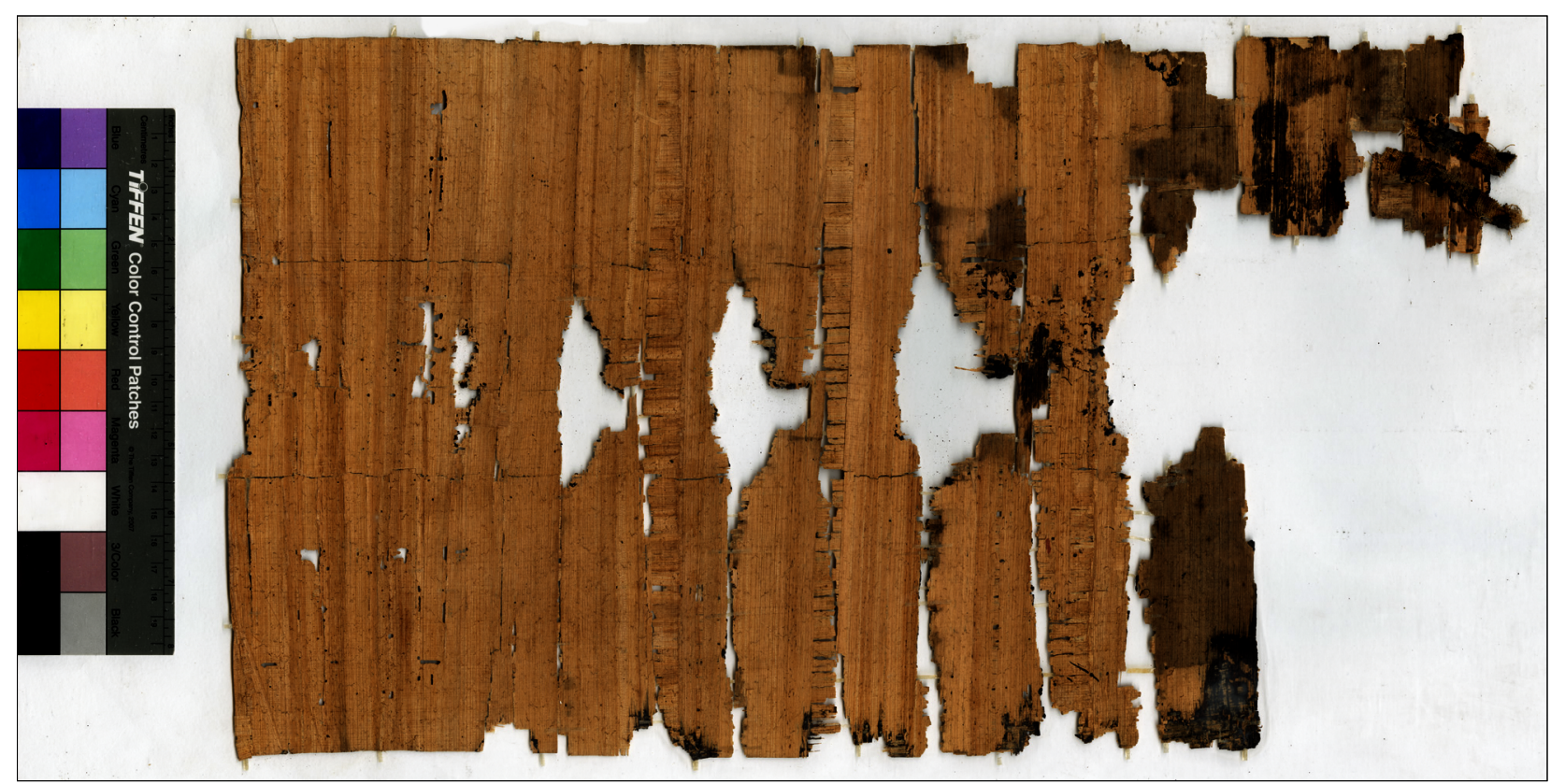

Fig. 2: P. Turin Cat. 2117 (R 08), verso, as currently mounted. Scan by Museo Egizio.

afterwards to close the rolled-up papyrus. ${ }^{4}$

Therefore, the two strips of linen with bitumen are most likely remains of the mummy bandages that were still attached to the papyrus roll after it had been torn from the mummified body to which it was tightly stuck because of the bitumen covering the mummy.

The papyrus displays a number of vertical cracks where it was bent after being rolled-up, as well as a regularly occurring horizontal pattern of dam- age, especially in the middle area. Both the fact that the first preserved column displays greater damage than the other sections and the fact that the vertical cracks occur at shorter intervals in the area of the blank protective sheet to the left indicates that the papyrus was rolled from left to right and the righthand side was hence the outermost. Furthermore, no traces of bitumen are visible on the verso of the protective sheet, as this was on the inside of the roll. Although the bad state of preservation of the manu- 
script's first preserved column of text makes it difficult to ascertain whether this was originally the first column of the manuscript or whether more text had preceded it, several factors suggest that the whole document originally consisted of only these three columns. The fragment that is currently attached to the lower right edge of the papyrus, just before the first column, offers the first hint. It needs to be shifted $2.5 \mathrm{~cm}$ downwards until its bottom line is aligned with the bottom line of the main part. On the verso of the fragment, one can still see traces of bitumen where the two strips of bandages were originally attached. These were reused in modern times to fix the fragment in its current position. The fact that it is entirely blank on the recto supports the hypothesis that there were no preceding columns of text. Furthermore, the traces of bitumen along the fragment's right edge - which stained the inward-facing recto of the rolled-up papyrus - suggest that this was the outermost and, hence, the first sheet of the document. Moreover, a closer look at the original reveals that the first visible pair of column separation lines (in the lower right corner) is also where the column frames start, as the horizontal double line does not extend rightward of this first separation. Another important argument is provided by the text itself, more specifically, its headline and the title of the deceased in the first two lines of the first column. As the following investigation will show, neither the title of the deceased nor an extensive headline occur again in the course of the composition. All these data concur in indicating that the total length of the original manuscript is preserved.

\section{The owner of P. Turin Cat. 2117 (R 08) and his family}

The manuscript gives us the names of its owner and his mother:

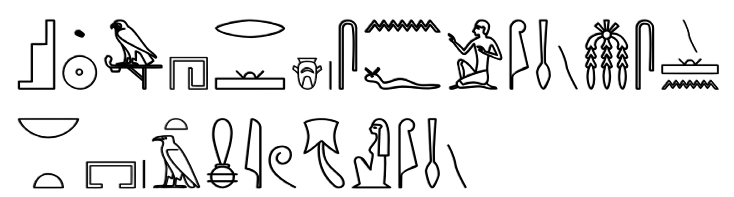

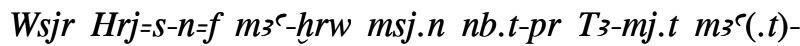
hrw, "the Osiris of Herisenef, ${ }^{5}$ justified, whom the mistress of the house Tamyt, ${ }^{6}$ justified, has born". This Herisenef is known from a number of other sources. A statue from the Cachette in Karnak, now in the Egyptian Museum in Cairo (RT 18/12/24/2), gives a detailed account of members of his direct family. According to this document, $H r j=s-n=f$ was the son of Ns-Mnw and T3-mj.t, and himself had two sons called $` n h-H^{\prime}{ }^{\prime} p j$ and $N s-M n w$. Furthermore, the whole family figures in several Theban Demotic administrative documents collected by Clarysse. ${ }^{8}$ They further reveal that Herisenef had a third son named P3-dj-Jmn. Based on the family tree constructed by Clarysse, the owner of P. Turin Cat. 2117 (R 08) can thus be identified with Herisenef I, who lived around 330 BCE $:^{9}$

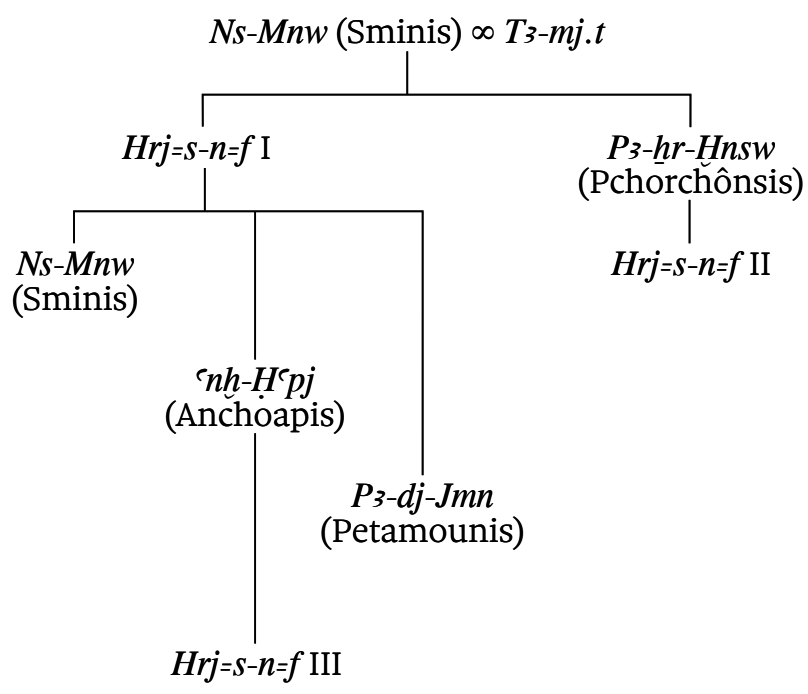

In addition to the material collected by Clarysse, Herisenef and other members of his direct family are known from documents of the "archive of Teos and Thabis" from Thebes. Our Herisenef (I) is mentioned in a witness list on a papyrus for selling a house (P. Brussels 8252), which dates to year 6 of Alexander the Great (327/6 BCE); he is the seventh in the list, identified as $H r j=s-n=f s 3 N s-M n w .{ }^{10}$ Moreover, in the witness list of P. Brussels 8254, dated to year 6 of Alexander IV (311 BCE), a certain Ns-Mnw, son of $H r j=s-n=f$ is named, who might be identical with the aforementioned son of Herisenef I. ${ }^{11}$

In the first line of the first preserved column of P. Turin Cat. 2117 (R 08), the title of the deceased Herisenef can be reconstructed with some certainty, as it is known for other members of his family ${ }^{12}$ and is also attested for him in a "Geldbezahlungsschrift"13 dated to year 3 of Alexander the Great (330/29 BCE): wn.w n pr-nbw n Jmn, "the shrine opener/pastophoros of the Gold House of Amun". ${ }^{14}$ No other titles, if they were originally written in the lacuna, are pre- 
served, and neither are additional titles of his listed in the administrative documents referred to above. According to the list provided by Depauw, which is based on the material he collected, only the members of Herisenef's family (he himself, his son Ankhhapi, and his brother Pakherkhonsu) bore the specific title "pastophoros of the Gold House of Amun". ${ }^{15}$ Ankhhapi also held the titles of "pastophoros of Amun" and swnw-jr.t, "ophthalmologist", ${ }^{16}$ and possessed two houses in the northern part of Thebes, in the district called "the House of the Cow", where his father likewise resided. ${ }^{17}$

\section{Discussion of the text inscribed and parallels}

The papyrus is inscribed with the final columns of a composition known today by Egyptologists as the so-called Glorifications I. ${ }^{18}$ This composition is a compilation of 18 or 16 spells (depending on the subdivision of the text) that were used in the cult of the god Osiris in Abydos. ${ }^{19}$ This text's introductory lines - preserved in P. BM EA 10252, col. 36, 11. $1-2^{20}$ - give instructions for its performance: $s 3 h . w$ jirj $m$ ḥw.t-ntr n.t Wsjr jn hrij-ḥb hrj-tp $m$ pr pn $\underline{d d . w}$ $m$ tp-tr $n b n$ web.t jrj mrj.t $m$ зbd smd.t $m$ hb nb n.w jmnt.t, "Glorifications, which are performed in the temple of Osiris, by the chief lector priest of this house. What is said on each due occasion of the embalming place. What is desired should be performed at the month-festival, the fifteenth day festival, and at every festival of the West". However, as Smith has already pointed out, the designation Glorifications I - just as the other three books called Glorifications II, III, and IV - is a modern one and its use problematic, especially considering that each of these compositions has an ancient Egyptian title of its own, like the one just translated above. ${ }^{21}$

The main purpose of these spells is to assert "that the dead will be revived, protected, nourished, and accepted among the underworld gods and their followers". 22 As they are hence intended to highlight what will happen, instead of wishing for it to happen, the main verb form used is the future $s d m=f$, addressing the person who is supposed to benefit from it in the second person singular. ${ }^{23}$ Since the version on P. Turin Cat. 2117 (R 08) was originally intended for funerary purposes - and thus, unlike P. BM EA
10252, was not an original temple manuscript that was only later reused for funerary purposes - Wsjr $N N$ is added after Wsjr hntj jmnt.t throughout the composition. However, it should be pointed out that in the parallel version of the Glorifications I in P. BM EA 10317 - which was likewise originally intended for funerary use - solely Wsjr $N N$ is present, whereas Wsjr hntj jmnt.t is omitted entirely.

The complete composition of the Glorifications I is currently known to be preserved on five papyri:

P. BM EA $10317^{24}$ can be dated to around 300 BCE. It belonged to $\underline{D} d-h r$, also called $P_{3-j}{ }^{\imath} n y$, who is the owner of two other papyri in the Museo Egizio: P. Turin Cat. 1830 (Book of the Dead) and P. Turin Cat. 1845 (Glorifications III) + CGT 54047 (Ritual for Bringing Sokar out of the Shrine). Djedher was buried in the tomb of Ankhhor in the Asasif (TT 414) together with his family members, and this location is thus the presumable find-spot of these papyri. ${ }^{25}$

P. BM EA $10319^{26}$ can likewise be dated to around 300 BCE. It belonged to the priest P3-hr-Hnsw, the brother of the aforementioned Djedher. He further possessed a Book of the Dead, currently kept in the Museo Egizio (P. Turin Cat. 1832). ${ }^{27}$

P. BM EA $\mathbf{1 0 2 5 2}^{28}$ is dated to $307 / 6$ BCE by a colophon written on it. It most likely formed one consecutive papyrus roll with P. BM EA 10081. These documents originally belonged to a temple library and were only later adapted by a certain $P_{3}$-wrm, who possessed a number of funerary papyri. The exact find spot of the papyrus is not known, but it certainly comes from Thebes.

P. Berlin P. 3057 (P. Schmitt) ${ }^{29}$ dates to around 300 BCE. Its owner as well as its provenance are unknown.

P. Louvre N. $3129^{30}$ can be dated to the $4^{\text {th }}$ or $3^{\text {rd }}$ century BCE. It belonged to the priest $P$ 3-šrj-n-Mnw, who was also called Wsjr-wr. Its provenance in not known. Furthermore, four other papyri contain excerpts, although none is parallel to the spells preserved on the papyrus of Herisenef: P. Cracow Jagiellonen University Library 03.03.1992 (= P. Sȩkowski) ${ }^{31}$ can be dated to Roman times and contains Spells 1-4 of the Glorifications I; P. Asasif 7 (Psametik), ${ }^{32}$ dating to the early Ptolemaic Period, preserves Spells 3-4; P. Leiden $\mathrm{T} 31,{ }^{33}$ also dating to the early Ptolemaic Period, contains Spells 7-8; and P. Barcelona Palau-Rib. inv. 


\begin{tabular}{|l|c|c|}
\hline Sign & Hieratic & Position \\
\hline col. 2, I.2 \\
\hline
\end{tabular}

Table 1: Overview of some of the most distinctive signs in P. Turin Cat. 2117 (R 08). 
80/68, ${ }^{34}$ from the early Ptolemaic Period, preserves Spells 8-10. The provenance of P. Sȩkowski, P. Leiden T31, and P. Palau-Rib. inv. 80/68 is not known, whereas P. Asasif 7 was found in the excavation of the tomb of Mutirdis in Asasif (TT 389). ${ }^{35}$ In addition, a number of excerpts are known from sarcophagi of the Ptolemaic Period, and from the Hourly Vig$i l$ in the temple of Edfu. ${ }^{36}$

The text of P. Turin Cat. 2117 (R 08) is written in hieratic, in scriptio continua, filling each line completely. The scribe used red ink for the introductory rubrics mentioning the $s 3 h w^{37}$ or $k j$, "another", 38 as well as for the invocation $h 3 y^{39}$ and mentions of the enemies. ${ }^{40}$ The version on P. Turin Cat. 2117 (R 08) consists of a total of 9 invocations - structured by means of $h 3 y$ and, once, $k j$ - corresponding to Spells 14-16 as numbered by Assmann. ${ }^{41}$

\section{Layout and palaeography}

The first two columns are enclosed by frames consisting of two black lines, whereas the third column is written without any framing lines or other markers for orientation. This column is also much narrower than the other two, although there was more writing space to the left on the papyrus. The width of the column eventually turned out to be insufficient, so that the scribe had to stop writing before the actual end of the text.

The double-lined borders are unusual for liturgical papyri of the early Ptolemaic Period. In P. Sękowski, however, which dates to Roman times, the individual columns are likewise enclosed by two black lines. ${ }^{42}$ Moreover, black double-lined borders just like those of P. Turin Cat. 2117 (R 08), are commonly used in hieratic Books of the Dead of the Late and Ptolemaic periods. ${ }^{43}$ It is known that the framing lines or borders for these Book of the Dead spells were drawn on the papyrus sheets before they were assembled, ${ }^{44}$ and this would explain the layout of the papyrus of Herisenef: the sheet, already prepared with framing lines, may have been originally intended for Book of the Dead spells, but was then repurposed and used for glorification spells.

As argued in the previous sub-chapter, the papyrus can be dated to around $330 \mathrm{BCE}$ and comes from Thebes. As we are in the fortunate position of having a date and provenance for this manuscript, it is worth dwelling on its palaeography (see Table 1), as this could be useful for comparative studies. The handwriting of the scribe appears swift, with little attention to detail; compare, for instance, (W 19) in col. 2, 1. 17, where he placed the upper part of the sign too far to the left. He tried to simplify/abbreviate the hieratic signs as much as possible. On the other hand, however, one should note the elaborate writing of the scarab sign (L 1). There are a few characteristic signs that distinguish our scribe, such as his writing of $\longrightarrow$ (D 21) with a rather prominent downward stroke on the right-hand side, or his writing of (P 1), where he seems to add a supplementary vertical stroke to the horizontal base line. ${ }^{45}$

\section{Transliteration, translation, and commentary}

\subsection{First invocation: col. 1, II. 1-4}

This corresponds to Spell 14, "Erster Abschnitt" (following Assmann's subdivision of the text). ${ }^{46}$

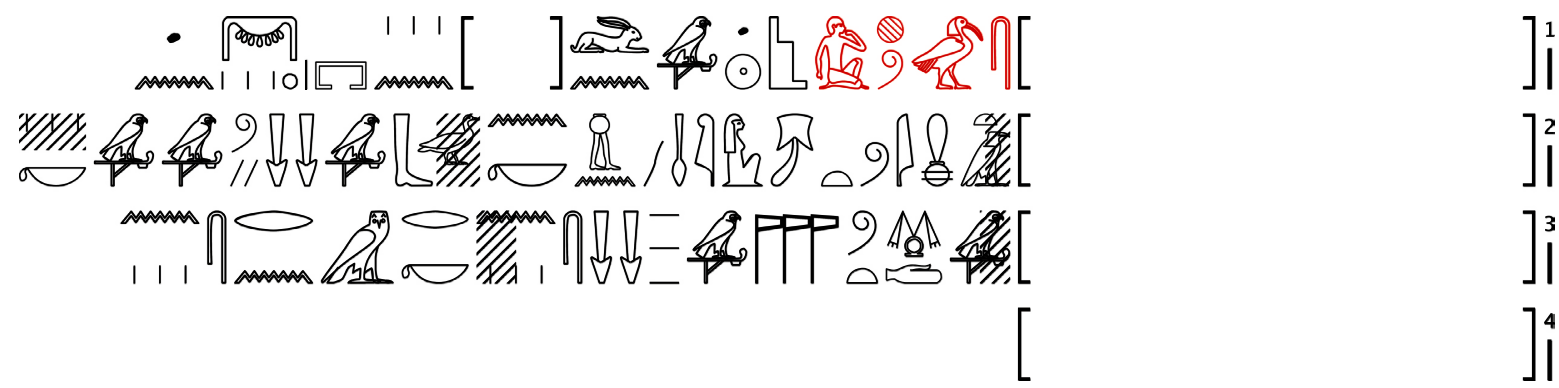

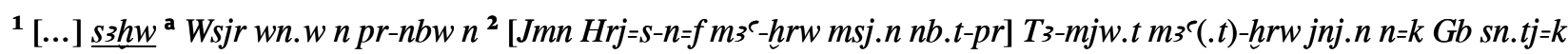

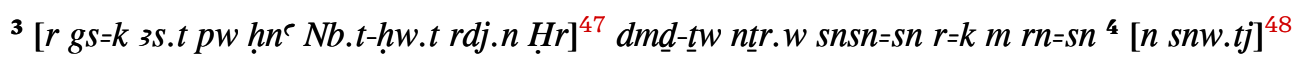


" 1 [...] ${ }^{\mathrm{b}}$ Glorification of the Osiris of the shrine opener/pastophoros of the Gold House of ${ }^{\mathbf{2}}$ [Amun ${ }^{\mathbf{c}}$ Herisenef, justified, whom the mistress of the house,] Tamyt, justified, [has born]. Geb has brought for you your two sisters ${ }^{3}$ [to your side. It is Isis together with Nephthys. Horus has caused] that the gods assemble/join with you, that they are brotherly towards you in their name ${ }^{4}$ [of the two snw.t-shrines]."

a The parallels add $h(3)$, "Hail"; compare P. Schmitt, col. 17, 1. 7; P. BM EA 10252, col. 48, 1. 1; P. BM EA 10319, col. 11, 1. 25.

${ }^{b}$ As the parallels all start with $s 3 \mathrm{~h}$ and do not have any text before it, it is impossible to reconstruct the beginning of the line in P. Turin Cat. 2117 (R 08) with any certainty. Nevertheless, since it seems that our version of the Glorifications I started at this point and presumably only consisted of these three columns, the beginning of the line might have included a short introduction concerning the broader purpose of the collection of glorifying spells that follow..$^{49}$ Nevertheless, the ancient Egyptian title of the whole composition, designated as Glorifications I nowadays, is $m$ d $3 . t n . t s 3 h w$, $h$, "Book of glorifying the spirit" in the version of P. Segkowski, col. 10, 1. 1, ${ }^{50}$ which, just like our version, does not have the complete text, but only a selection of several of the spells; it is hence probable that $m$ d $3 . t$ n.t szhw Wsjr NN, "Book of glorifying the Osiris of NN" or a similar title was originally written at the start of the text on P. Turin Cat. 2117 (R 08). The title in P. Leiden T31, which likewise only made use of a couple of spells (7-8), reads jnj $r$ szh h3y, "Extract from the (Book of the) Glorification 'Hail'", ${ }^{51}$ so an $j n j$-phrase for introducing an excerpt could have originally been written in the lacuna as well. ${ }^{52}$

' Compare the remarks above under "The owner of P. Turin Cat. 2117 (R 08) and his family" for this restoration of the title in the lacuna. For the title wn.w, "shrine opener/pastophoros", see Jelínková-Reymond, $C d E$ 28 (1953), pp. 53-59; Ramond, JEA 65 (1979), p. 170, n. (d); Johnson (ed.), CDD_W, 2009, pp. 89-92, and the literature references cited in these works. For the wn.w $n$ pr-nbw $n$ Jmn more specifically, see Johnson (ed.), CDD_P, 2010, p. 57.

\subsection{Second invocation: col. 1, II. 4-7}

This corresponds to Spell 14, "Erster Abschnitt". ${ }^{3}$

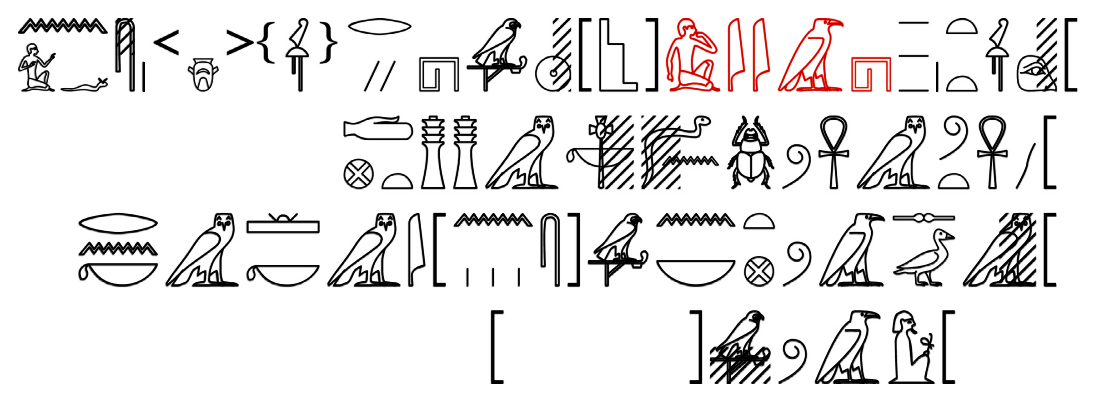

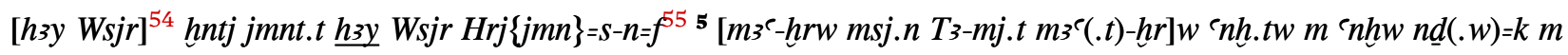

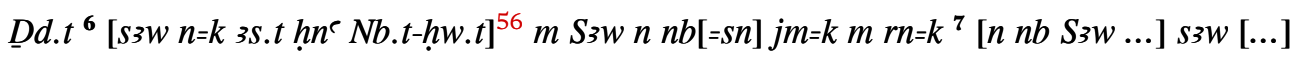

"[Hail Osiris], foremost of the West, hail the Osiris of Herisenef, ${ }^{\mathbf{5}}$ [justified, whom Tamyt, justified, has born], you are alive like/as the living one (the beetle), you will be protected in Mendes. ${ }^{57} \mathbf{6}$ [Isis and Nephthys will exercise protection for you] in Sais, for [their] lord which you are, in your name ${ }^{7}$ [of lord of Sais ...] the guard$\operatorname{ian}(?)[\ldots]^{\mathrm{d}}$

d As our copy seems to deviate here from the known parallels, a reconstruction seems impossible for this section. P. Schmitt, col. 17, 11. 9-10; P. BM EA 10252, col. 48, 11. 7-8, and P. BM EA 10317, col. 14, 1.4 read: ... $n b S 3 w n t r=s n j m=k m r n=k n n t r r p 3 . w t$, "... lord of Sais, ${ }^{58}$ their god which you are, in your name of god of the 
nomes". Considering the position of $s 3 w$ in our text, maybe P. Turin Cat. 2117 (R 08) once read $s 3 w s p 3 . w t$, "guardian of the nomes" 59 instead of $n t r$ sp3.wt, "god of the nomes".

\subsection{Third invocation: col. 1, II. 7-12}

This corresponds to Spell 14, "Zweiter Abschnitt". 60

A fragment that belongs to this section is currently misplaced to the left, in col. $2 .{ }^{61}$
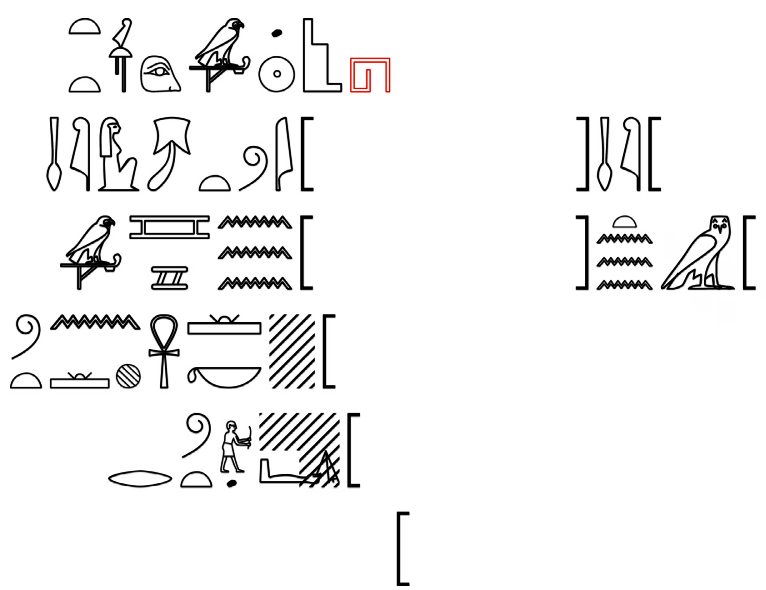

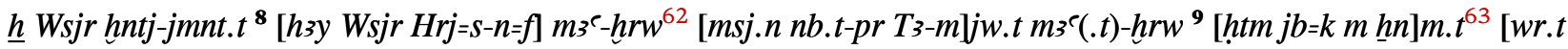

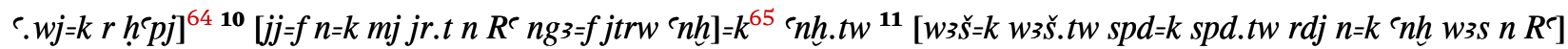
$h 3 w . t w r^{12}[h f t j . w=k]^{66}$

"Hail Osiris, foremost of the West, ${ }^{\mathbf{8}}$ [hail the Osiris of Herisenef,] justified, [whom the mistress of the house Tam]yt, justified, [has born], ${ }^{\mathbf{9}}$ [quench your thirst in the great w]ell, [your arms towards the Nile inundation.] ${ }^{\mathbf{1 0}}$ [It will come for you like that which is done for Re. It will break open the river.] You [will live,] being alive. ${ }^{\mathbf{1 1}}$ [You will be honoured, being honoured. You will be effective, being effective. The ' $n h$-sign and the w3s-sceptre of Re will be given to you, so that] you are protected from ${ }^{\mathbf{1 2}}$ [your enemies.]"

\subsection{Fourth invocation: col. 1, II. 12-16}

This corresponds to Spell 14, "Dritter Abschnitt". ${ }^{67}$

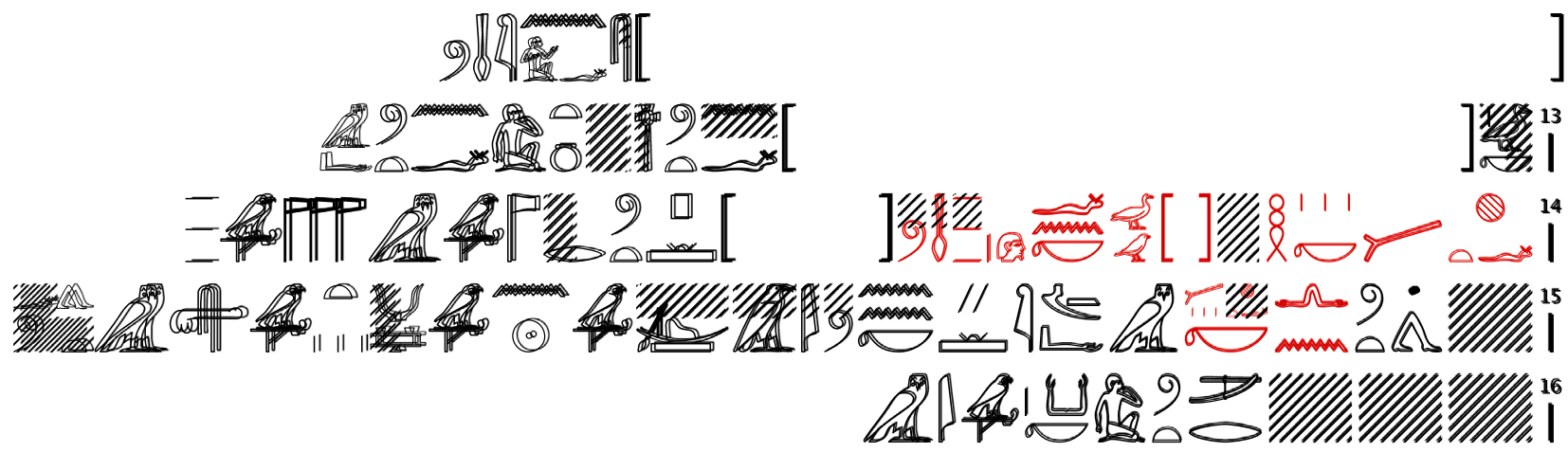

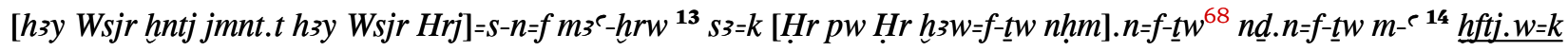

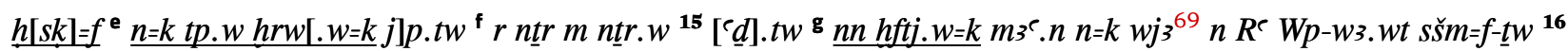
$[r b w n b]^{70} m r w . t k 3=k j m$

"[Hail Osiris, foremost of the West, hail the Osiris of Heri]senef, justified, ${ }^{\mathbf{1 3}}$ your son [Horus is it. Horus, he will protect ${ }^{\mathrm{h}}$ you,] he [rescue]d you, he saved you from ${ }^{14}$ your enemies. He will cut [off] for you the heads 
of [your] foe[s,] while you are [count]ed as god among the gods, ${ }^{\mathbf{1 5}}$ while you are [safe]. Your enemies do not $\underline{\text { exist. The barque }}{ }^{\mathrm{i}}$ of Re was led for you. Wepwawet, he will guide you ${ }^{\mathbf{1 6}}$ [to every place] where your ka desires (to go)."

e The parallels have hsk; compare P. BM EA 10252, col. 48, 1. 16; P. BM EA 10317, col. 14, 11. 9-10; P. BM EA 10319, col. 11, 1. 35; P. Schmitt, col. 17, 1. 12. The determinative that is still preserved, however, would rather argue for htm, "to destroy".

${ }^{f}$ The lacuna is filled according to P. BM EA 10252, col. 48, 1. 16; P. BM EA 10317, col. 14, 1. 10; P. BM EA 10319, col. 11, 1. 36; P. Schmitt, col. 17, 1. 13. The traces in front of the lacuna would also allow the reading ... tp.w $n . w$ [hrw. $w=k$... with genitival $n . w$, depending on how elaborately the word $h r w . w$ was written in the lacuna. ${ }^{71}$ g Restoration according to P. BM EA 10252, col 48, 1. 17; P. BM EA 10319, col. 11, 1. 36. P. Schmitt, col. 17, 1. 13 has '.$t w$, "while you enter".

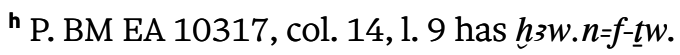

' The parallels have w3.t, "way" here; compare P. BM EA 10317, col. 14, 1. 10; P. BM EA 10319, col. 12, 1. 1; P. Schmitt, col. 17, 1. 13. For the sense of this passage, see also a section from Book of the Dead Spell 149: $h_{3 j} j=j$ hr jdb.w nt sktj $r$ w3.t m3 ${ }^{r} . t$, "I descend to the shores of the solar barque, to the correct way." ${ }^{2}$

\subsection{Fifth invocation ("address to the bringer of bas"): col. 1, I. 16-col. 2, I. 6}

What follows is the so-called "address to the bringer of bas", sometimes also designated as Book of the Dead Spell 191, which is not only known from papyri, but was also very prominent on Late Period coffins and can hence be considered as popular. ${ }^{73}$ In addition, an excerpt of this "address to the bringer of bas" is found on a so far unique hypocephalus (Stockholm MME 1977:6), where it replaces the more usual Book of the Dead Spell $162 .{ }^{74}$

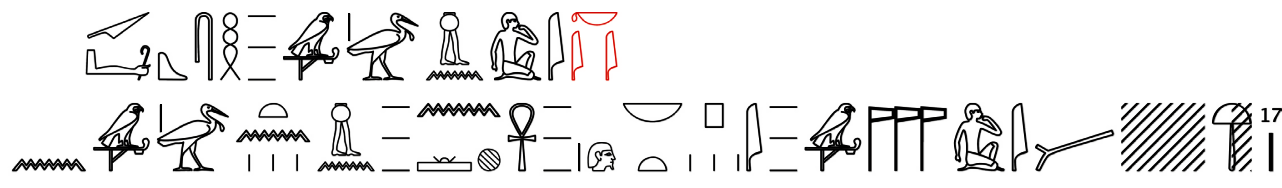

col. 2

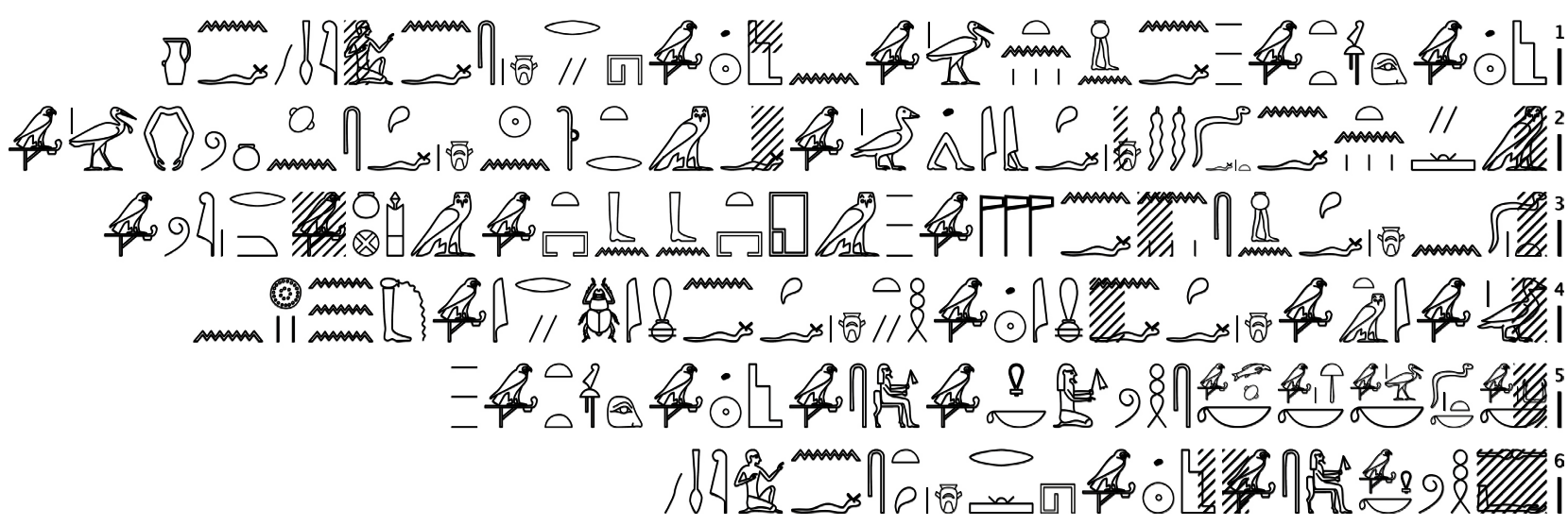

$\underline{k y} j$ jnj b3.w hsk ${ }^{17}[\check{s} w . w t]^{75} j$ ntr.w jp.w nb tp(j).w 'nh.w jnj=tn $b_{3} n^{\text {col. 2,1 }}$ Wsjr hntj jmnt.t $n=f j n j=\underline{t n} b_{3} n$ Wsjr

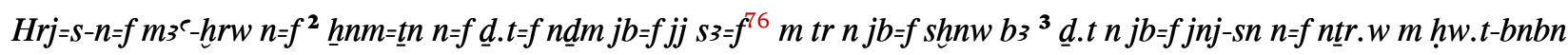

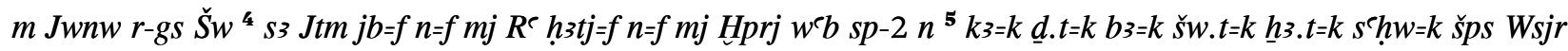
hntj jmnt.t ${ }^{6} s^{c} h w=k$ šps Wsjr $H r j=s-n=f m 3^{c}-h r w$

"Another: O bringer of bas, who cuts off ${ }^{\mathbf{1 7}}$ [shadows], o all these gods, who are at the head of the living, ${ }^{77}$ may you bring the ba of ${ }^{\mathbf{c o l} . \mathbf{2 , 1}}$ Osiris, foremost of the West for/to him, may you bring the ba of the Osiris of 
Herisenef, justified, for/to him. ${ }^{2}$ May you unite his body for him, that his heart may be glad. His son will come at the (correct) time ${ }^{78}$ according to his wish. ${ }^{79} \mathbf{j}$ May the ba embrace/unite ${ }^{\mathbf{3}}$ the body and his heart. ${ }^{\mathbf{k}}$ Bring them for him, gods, in the Benben-house in Heliopolis, in the presence of Shu, ${ }^{4}$ the son of Atum. His $j b$-heart is for/belongs to him like Re, his $h 3 t j$-heart is for/belongs to him like Khepri. Purification, twice, for $\mathbf{5}$ your ka and your body, your ba and your shadow, your corpse and your noble mummy, ' Osiris, foremost of the West, ${ }^{\mathbf{6}}$ your noble mummy, the Osiris of Herisenef, justified."

' Our version deviates from the parallels, the reason for which seems to have been confusion and/or misunderstanding. Nevertheless, the sentence here makes sense as it is written. The parallels read: $j w b z=f n \underline{d} . t=f n$ $j b=f$, "May his ba come to his body and to his heart." ${ }^{\circ 0}$

" Some of the parallels add $h t m b z=f n d . t=f n j b=f$, "May his ba be complete/provided with his body and his heart" (or similar) here. ${ }^{81}$

' P. Schmitt, col. 17, 1. 17; P. BM EA 10319, col. 12, 1. 7; P. BM EA 10317, col. 14, 1. 16 reverse the order of $s$ w.t $t=k$ and $\underline{h} . t=k .{ }^{82}$ In addition, P. BM EA 10317, col. 14, 1.16 and P. Schmitt, col. 17, 1.17 add $n$, "for" in front of $\underline{d} . t=k$, $b_{3}=k, \underline{h} 3 . t=k$, and $\check{s} w . t=k$.

\subsection{Sixth invocation: col. 2, II. 6-11}

This corresponds to Spell 15, “Erster Abschnitt” (again, following Assmann's subdivision of the text). ${ }^{83}$

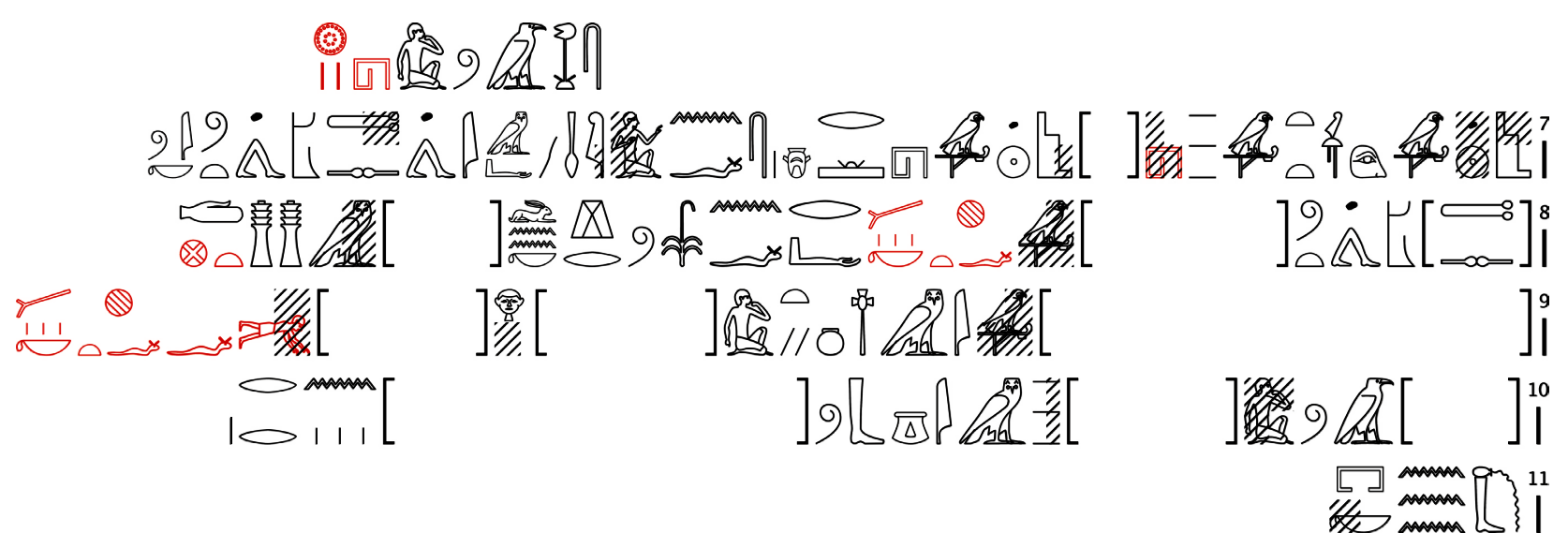

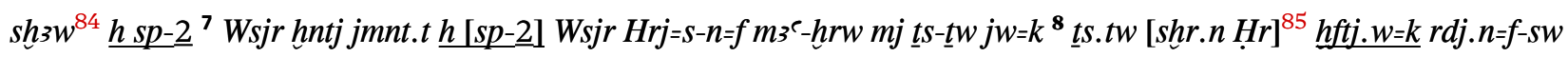

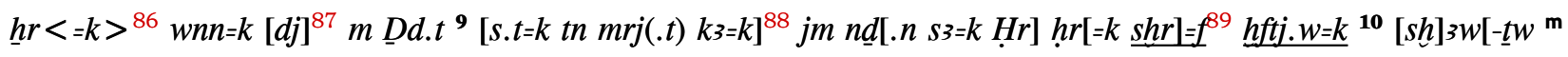
$s n . t j]^{90} m$ jgbw[=sn $\left.h^{C j}=s\right] n^{91} r r^{11} w^{\top} b(. t)=k^{\mathbf{n}}$

"Remembrance. Hail, twice, ${ }^{7}$ Osiris, foremost of the West, hail, [twice,] the Osiris of Herisenef, justified, come and raise yourself! You are ${ }^{\mathbf{8}}$ risen. [Horus has overthrown] your enemies and he has placed him (= the enemy $=$ Seth) under $<$ you $>$. You will be [here] in Busiris, ${ }^{92} \mathbf{9}$ [this your seat,] where [your ka wants to be. Your son Horus has] greet[ed you.] He [will fell] your enemies. ${ }^{\mathbf{1 0}}$ [The two sisters will remem] ber [you] with [their] mourning. [They will mourn/wail] at the door ${ }^{11}$ of your Wabet."

${ }^{\mathrm{m}}$ For $s h 3 w$ being written instead of $s 3 h w$, see also above in col. 2, 1. 6. The parallels have $s 3 h$; compare, for instance, P. BM EA 10252, col. 49, 11. 5-6; P. BM EA 10317, col. 15, 1. 3, or P. Schmitt, col. 17, 1. 20.

${ }^{n}$ P. BM EA 10317, col. 15, 1. 4; P. Schmitt, col. 17, 1. 20; P. BM EA 10319, col. 12, 1.14 read $r r 3 n w^{c} b . t=k$. 


\subsection{Seventh invocation: col. 2, II. 11-17}

This corresponds to Spell 15, "Zweiter Abschnitt". 93

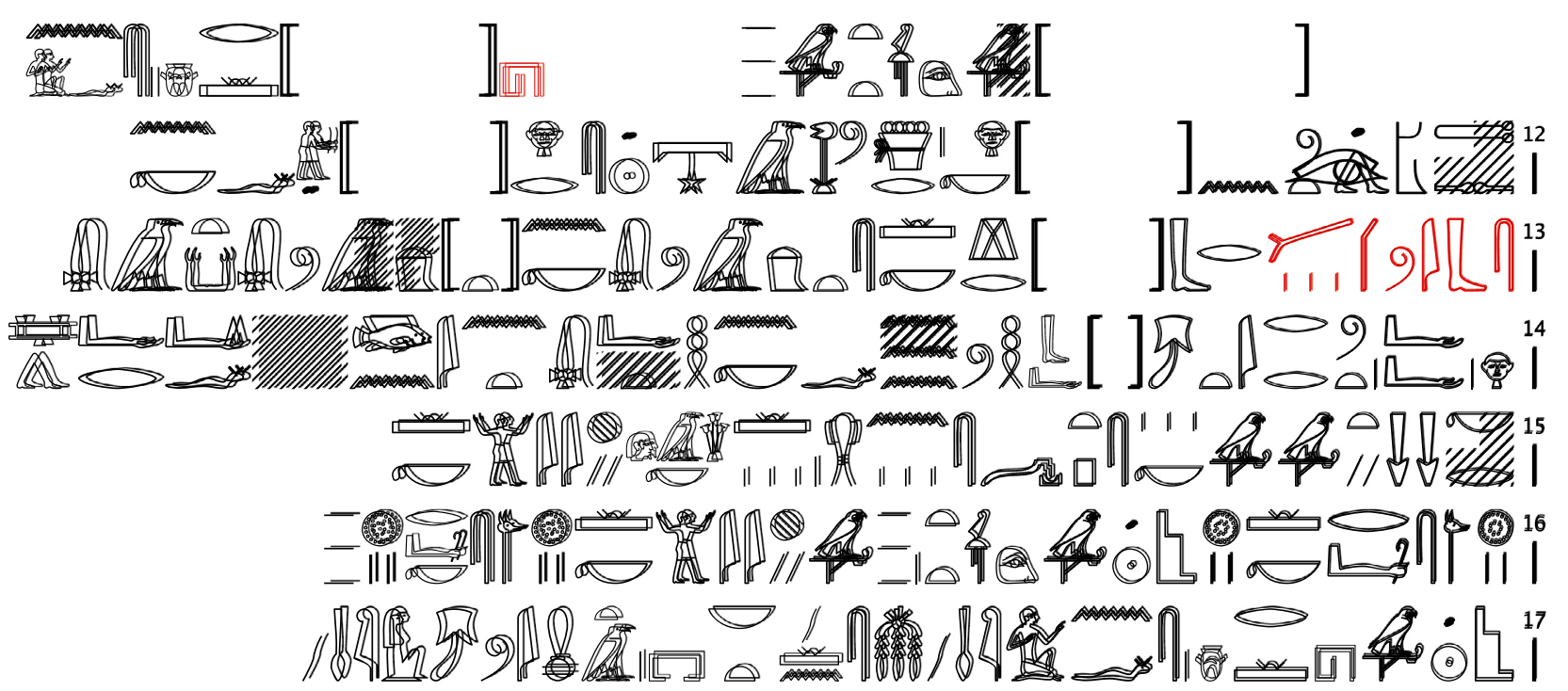

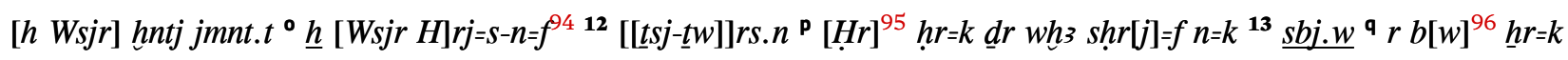

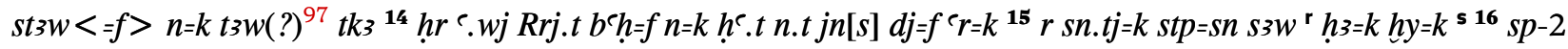

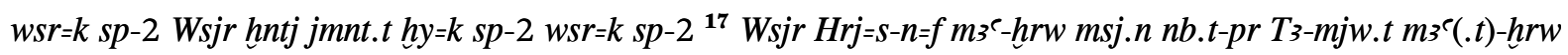

"[Hail Osiris], foremost of the West, hail [the Osiris of H]erisenef, ${ }^{\mathbf{1 2}}$ [Horus] has [[raised you]] watched over you since the darkness. He will drive away for you ${ }^{\mathbf{1 3}}$ the rebels from the pla[ce], where you are. $<$ He> will light for you the heat(?) of the torch ${ }^{\mathbf{1 4}}$ on the arms of Reret. He will inundate for you the wick of bright-red lin[en]. He will cause you to ascend ${ }^{\mathbf{1 5}}$ to your two sisters, and they will exercise protection around you. You will rise up, ${ }^{16}$ twice, you will be strong, twice, Osiris, foremost of the West! You will rise up, twice, you will be strong, twice, ${ }^{17}$ the Osiris of Herisenef, justified, whom the mistress of the house Tamyt, justified, has born!"

- The scribe of our version left a blank space of $2 \mathrm{~cm}$ between the invocation to Osiris, foremost of the West, and the one to the Osiris of Herisenef, for reasons I do not see. He was probably confused and wanted to leave the space in front of the call to Osiris, foremost of the West, in order to separate the following invocation from the preceding one.

P The scribe first wrote $?$ curred a couple of times in the text (col. 2, 11. 7, 8). He then seems to have realised his mistake and corrected 9 into $\underset{\mathbb{S}}{2}$, thus changing the word ts into $r$.

q P. Schmitt, col. 17, 1.21 has $s b j . w=k$, "your rebels".

' P. BM EA 10252, col. 49, 11. 13-14; P. BM EA 10317, col. 15, 1. 7; P. BM EA 10319, col. 12, 11. 17-18, and P. Schmitt, col. 17, 1. 23 have $s 3 w=s n$, "their protection".

${ }^{\mathbf{s}}$ The parallels have the single sign ${ }^{2} \mathrm{~A}$ here, so maybe our version proves that this likewise needs to be read hy instead of $k .3 j$ in the parallels. ${ }^{98}$

\subsection{Eighth invocation: col. 3, II. 1-12}

This corresponds to Spell 16, “Zweite Strophe” (following Assmann's division of the text). ${ }^{99}$

The version of P. Turin Cat. 2117 (R 08) omits the final three invocations of Spell 15 as well as the first and the second invocation of Spell 16, probably due to shortage of space. The following column is added without any framing lines. 


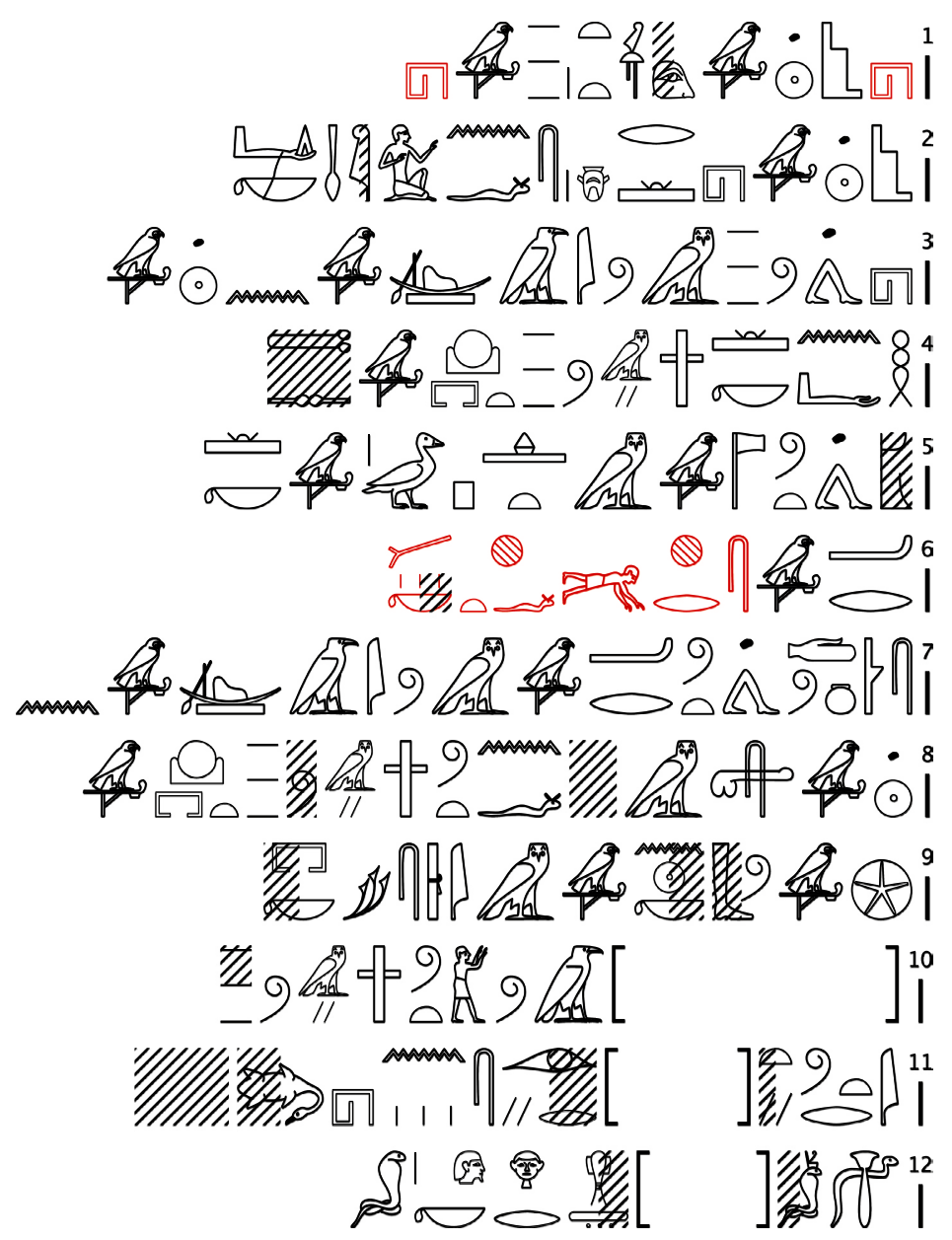

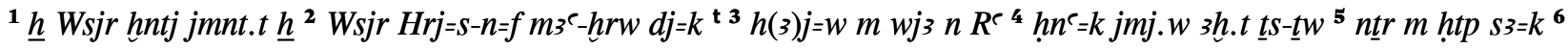

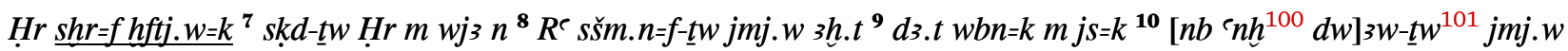
${ }^{11} j t r[. t j] j r j=s n h(3)-s n \underline{d}[n]^{102} 12$ ws $\underline{d}[. t j=k]^{103} s 3-t 3$ hrj $(. t)-t p=k$

${ }^{\text {" }}$ Hail Osiris, foremost of the West, hail ${ }^{\mathbf{2}}$ the Osiris of Herisenef, justified. You will cause ${ }^{\mathbf{3}}$ them to descend to the barque of Re, ${ }^{4}$ together with you (and) the ones who are in the horizon. ${ }^{\mathbf{u}}$ Raise yourself up, ${ }^{\mathbf{5}}$ god, in peace! Your son ${ }^{6}$ Horus, he will fell your enemies. ${ }^{7}$ Horus will sail you in the barque of ${ }^{\mathbf{8}}$ Re. He has led you $<$ to $>$ " the ones who are in the horizon ${ }^{\mathbf{9}}$ and the underworld ${ }^{\mathbf{w}}$, (so that) you rise/shine in your tomb, ${ }^{\mathbf{1 0}}$ [the lord of life]. Those who are in ${ }^{\mathbf{1 1}}$ the [two] rows of shrines [will pra]ise you. They will show veneration [for] ${ }^{\mathbf{1 2}}$ [your two] serpent goddesses, and adoration $<$ for $>^{104}$ the one who is on your head (i.e. uraeus)."

${ }^{\mathbf{t}}$ The scribe initially ended the line with $/ 84$, but then decided to write $h r w$, probably because he had already continued with $h_{3 j}$ and then realised his accidental omission of $d j=k$.

" The scribe of our version reinterpreted the original sense of this sentence, which is $d j n=k h w m w j 3 n R^{\complement} h^{c} j$ $n=k$ jmj.w 3 h.t, "Shouting/jubilation will be given for you in the barque of Re, the ones who are in the horizon rejoice for you" in the parallels. ${ }^{105}$

" The parallels add the preposition $n$; see, for instance, P. BM EA 10252, col. 50, 1. 13; P. BM EA 10319, col. 12, 1. 36; P. Schmitt, col. 17, 1. 33. P. BM EA 10317, col. 16, 1. 10 has sšm=n[-t $t] w$... "we will guide you to ...”.

w The parallels have only jmj. $w$ d 3 .t; compare, for instance, P. BM EA 10252, col. 50, 1. 13; P. BM EA 10317, col. 16, 1. 10; P. BM EA 10319, col. 12, 1. 36; P. Schmitt, col. 17, 1. 34. The scribe of our text was perhaps reminded of the earlier jmj.w 3h.t (col. 3, 1.4). 


\subsection{Ninth invocation: col. 3, II. 12-19}

This corresponds to Spell 16, "Dritte Strophe". ${ }^{106}$

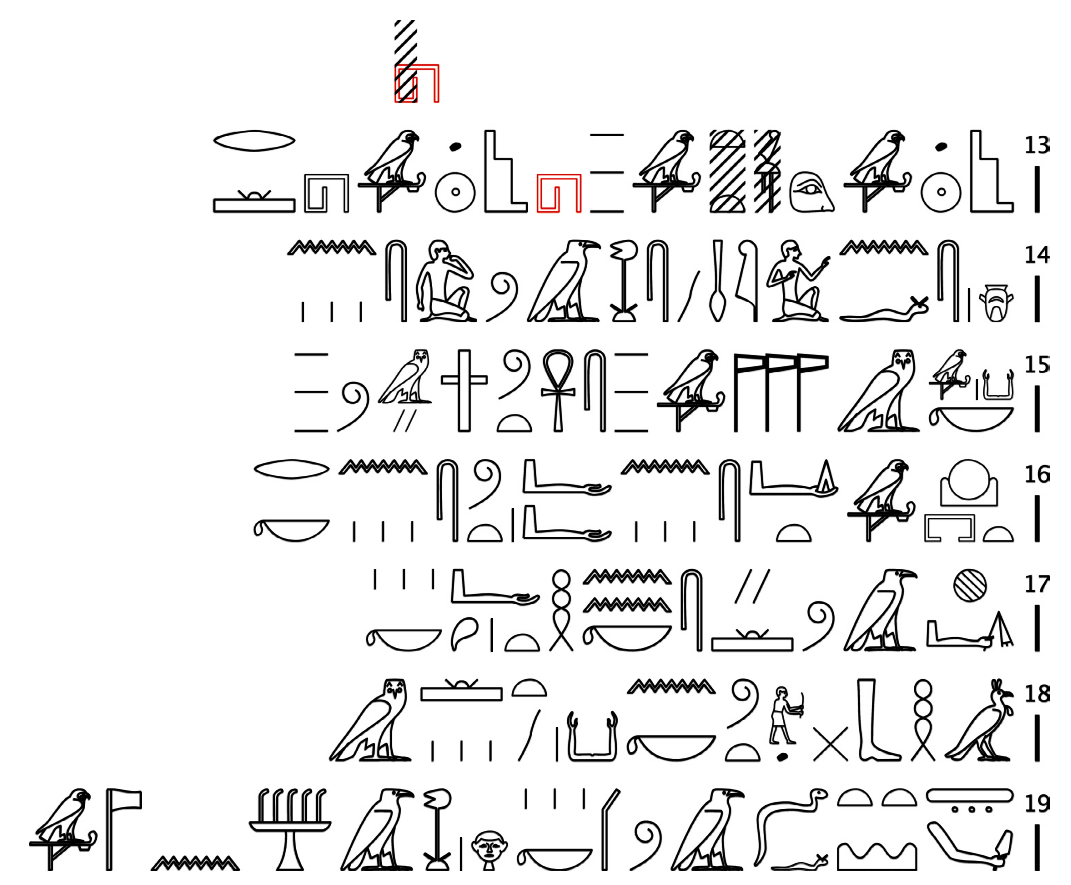

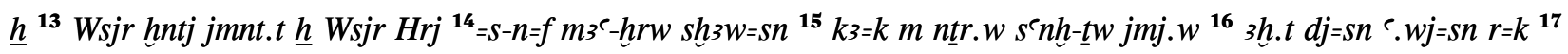

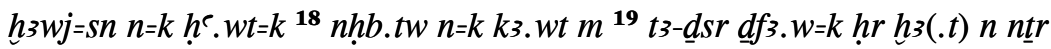

"Hail ${ }^{\mathbf{1 3}}$ Osiris, foremost of the West, hail the Osiris of Herisenef, ${ }^{\mathbf{1 4}}$ justified. They will remember ${ }^{\mathbf{1 5}}$ your ka among the gods. The ones who are in ${ }^{\mathbf{1 6}}$ the horizon will make you live. They will extend their arms towards you. ${ }^{\mathbf{1 7}}$ They will protect your limbs for you. ${ }^{\mathbf{1 8}}$ One will provide food for you in ${ }^{\mathbf{1 9}}$ the Sacred Land and your provisions on the altar of the god.”x

× The parallels add $s h m=k j m$ 'nh $k 3=k j m$ htm.tw $m$ d.t $n \underline{\text { d.t. }}$, (so that) you will be powerful therewith and your ka will live therewith, while you are equipped with a body for ever" ${ }^{107}$ Our scribe stopped after $n \underline{t} r$, most likely due to shortage of space, as the column is entirely filled at this point.

\section{Concluding remarks}

P. Turin Cat. 2117 (R 08) contains a total of 3 columns, the number 3 representing plurality. Altogether it has 9 invocations, the number 9 being the plural of the plural and thus the symbol of totality. If this was done intentionally, it means that Herisenef made sure that he got a count representing allness in every respect. However, the number of columns and invocations might just as well be coincidental. Although Herisenef selected a rather short compilation for his funerary papyrus - compared to the extensive examples of collections of glorification spells of this period like on P. BM EA 10317 or P. Schmitt -, he made sure that every important aspect of this text category was included. According to Backes and Smith, the main characteristics of glorifications are: ${ }^{108}$

1. "Die Erweckung des Osiris/Verstorbenen zu neuem Leben" - "Revivification": 1, 3, 5, 6, 7, 8, 9

2. "Wiederherstellung und Schutz des Körpers" "Protection": 1, 2, 3, 4, 5, 6, 7, 8, 9

3. "Aufstieg zum Himmel bzw. allgemein Eintritt ins Jenseits", "Reise durch das Jenseits zum Sonnengott im Horizont”, "Empfang als Gott von hohem Status bzw. als Herrscher" - "Acceptance among the underworld gods and their followers": $\mathbf{4 , 5 , 8 , 9}$

4. "Zuweisung von Nahrung, meist den Opferspeisen des Re in Heliopolis" - "Nourishment": 9 The selection of glorifications that Herisenef chose for his funerary papyrus provides further answers to 
the question raised by Smith concerning the Glorifications, namely "to what extent and by how many scribes it was actually regarded as a unitary composition". ${ }^{109}$ P. Turin Cat. 2117 (R 08) is another piece in this puzzle that suggests that what is today very often designated as Glorifications I was not seen as a mandatory sequence of spells that belonged together in its entirety. The selection of spells - just like the compilations found in other manuscripts, such as P. Sȩkowski, or excerpts on objects - was regarded as an entity in its own right by the ancient scribe and not as part of a longer work.

Furthermore, we are in the fortunate position of possessing a wealth of additional information on the person who owned the funerary papyrus P. Tu-

\section{Notes}

${ }^{1}$ Fabretti et al., Regio Museo di Torino, 1882, p. 280, n. 1, no. 8.

${ }^{2}$ I would like to thank Arto Belekdanian, Thomas Christiansen, and Manon Schutz for their corrections and suggestions on earlier drafts of this article. I am further very grateful to Federico Poole and Susanne Töpfer (Museo Egizio) and Ilona Regulski (the British Museum) for their help, and to the anonymous reviewers for their corrections and improvements.

${ }^{3}$ Compare Gill, Ritual Books, forthcoming, chapter 3, for more information on this.

${ }^{4}$ I would like to thank Thomas Christiansen for pointing this out to me.

${ }^{5}$ See Ranke, $P N$, I, 1935, p. 230, (16) and (25); Lüddekens, Demotisches Namenbuch, 1991, pp. 751-52; Clarysse, CdE 53 (1978), p. 239, nn. 2 and 3. For the reading $H r j=s-n=f$ instead of $H r j-j b=s-n=f$, see Leahy, SAK 8 (1980), pp. 173-74, with n. 18.

${ }^{6}$ See Ranke, $P N$, I, 1935, p. 357, (5).

${ }^{7}$ The statue is not published, but compare the information and photographs on http://www.ifao. egnet.net/bases/cachette/?id=800 (last accessed on 28/05/2018). It is also discussed by Clarysse, $C d E$ 53 (1978), pp. 242-43. Depauw, Archive of Teos and Thabis, 2000, p. 95, (jj) describes it as "a cube statue of mediocre quality".

${ }^{8}$ Clarysse, CdE 53 (1978), pp. 239-43. See there for more members of Herisenef's family and compare the family tree provided here in the text.

${ }^{9}$ See Clarysse, CdE 53 (1978), p. 242, adding the Egyptian forms of the names to the ones provided in Greek by Clarysse.

${ }^{10}$ Depauw, Archive of Teos and Thabis, 2000, p. 81 and pl. 11.

${ }^{11}$ See Depauw, Archive of Teos and Thabis, 2000, p. 131, first witness, and pl. 24. The connection was also proposed by Depauw, Archive of Teos and Thabis, 2000, p. 136, (m). Another object from the Museo Egizio might also be attributed to the family. It is Cat. 2371 (see Fabretti rin Cat. 2117 (R 08), which is not the case for the majority of the other ritual manuscripts. In addition, most of the owners of papyri containing Osirian compositions held the title $j t-n \underline{t} r,{ }^{110}$ which was particularly important in rites involving Osiris, ${ }^{111}$ one that is, however, not attested for Herisenef in any of the documents covered above. What his only attested title, "pastophoros of the Gold House of Amun" does suggest is that Herisenef seems to have been affiliated with the temple of Karnak in Thebes.

Pl. 1: Recto of P. Turin Cat. 2117 (R 08) as currently mounted (C) Museo Egizio)

Pl. 2: Verso of P. Turin Cat. 2117 (R 08) as currently mounted (c) Museo Egizio)

et al., Regio Museo di Torino, 1882, p. 335 and the online database of the Museo Egizio, https://collezioni. museoegizio.it/it-IT/material/Cat_2371/?description= gatto\&inventoryNumber $=\&$ title $=\& \mathrm{cgt}=\& \mathrm{yearFrom}=\&$ yearTo $=\&$ materials $=$ provenance $=\&$ acquisition $=\&$ epoch $=\&$ dynasty $=\&$ pharaoh $=$ [last accessed on 20/08/2018]), a small wooden coffin that contains a mummified cat. The

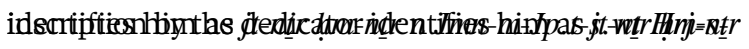
$n$ Jmn-m-Jp.t-s. wt Hrj=s-n=f sz jt-ntr hlm-ntr $n$ Jmn-m-Jp.t-s. wt Ns-Mnw jrj $n b(. t)-p r$ Ns-Hnsw, "the god's father, prophet of Amun in Karnak Herisenef, son of the god's father, prophet of Amun in Karnak Nesmin, whom the mistress of the house Neskhonsu made". Although Herisenef I is the son of a Nesmin, the name of the mother Tamyt is not identical, but it cannot be excluded that she had more than one name, as this is not uncommon. Nevertheless, Herisenef had a son called Nesmin, who again might have had a son called Herisenef, as his brother and uncle had. However, since I have not been able to find any other secure attestation of a son of this Nesmin, this suggestion must remain speculative.

${ }^{12}$ Compare the table by Depauw, Archive of Teos and Thabis, 2000, p. 33 (13, for ' $\left.n h-H^{`} p j\right)$, p. 35 (31, for $P_{3-}$ $h r$-Hnsw), and p. 42 (97, for $H r j=s-n=f$ I).

${ }^{13}$ P. Louvre 2439, 1. 2; compare Zauzich, Schreibertradition, I, 1968, pp. 10-12, and see the mention by Clarysse, CdE 53 (1978), p. 241.

${ }^{14}$ See Clarysse, CdE 53 (1978), p. 241. Zauzich, Schreibertradition, I, 1968, p. 11 translates "Pastophor des Amuntempels” for wn.w n pr nbw n Jmn.

${ }^{15}$ Depauw, Archive of Teos and Thabis, 2000, p. 53.

${ }^{16}$ Depauw, Archive of Teos and Thabis, 2000, p. 33, (13) and p. 53, and Clarysse, CdE 53 (1978), p. 239, with n. 5.

${ }^{17}$ Clarysse, CdE 53 (1978), pp. 239-41. For a detailed study on "the House of the Cow", see Depauw, Archive of Teos and Thabis, 2000, pp. 18-55.

${ }^{18}$ Compare the study by Assmann, Totenliturgien, III, 2008, pp. 37-225 and the relevant publications of the different versions listed in the following. See also 
the discussions by Smith, Traversing Eternity, 2009, pp. 167-71; Wüthrich and Stöhr, Ba-Bringer und Schattenabschneider, 2013, pp. 26-28.

${ }^{19}$ See Assmann, in Sarah Israelit-Groll (ed.), Fs Lichtheim, 1990, pp. 5-6 and fig. 2 on p. 32 for these divisions. Compare also Backes, Papyrus Schmitt, 2016, pp. 331-37 for the structure and function of the Glorifications I.

${ }^{20}$ Compare the photograph in Gill, Ritual Books, forthcoming, pl. 41. See also the translation by Smith, Traversing Eternity, 2009, p. 171.

${ }^{21}$ Smith, Traversing Eternity, 2009, p. 139.

${ }^{22}$ Smith, Traversing Eternity, 2009, p. 11.

${ }^{23}$ Smith, Traversing Eternity, 2009, pp. 11-12, 53, and 169.

${ }^{24}$ Unpublished; publication in preparation by F.-R. Herbin for the second volume of his catalogue Late Egyptian Religious Texts in the British Museum. For information about it, see Assmann, Totenliturgien, III, 2008, p. 19; Backes, in Burkhard Backes et al. (eds.), Liturgical Texts, 2015, p. 20 (where it is mistakenly dated to 200 BCE); Smith, Traversing Eternity, 2009, p. 168 and n. 8. I would like to thank Ilona Regulski (the British Museum) for sending me photographs of this manuscript.

${ }^{25}$ The connection of the three papyri to the same owner and their likely provenance from TT 414 was noted by Demichelis, Memorie Sc. Mor. 40 (2016), pp. 43-44 and see also the entry at: https://www.trismegistos. org/text/57047 (last accessed on 26/05/2018). See also Gill, "The funerary papyri of the brothers Djedher (TT 414) and Pakherkhonsu in the Museo Egizio and the British Museum, with some observations on scribal practices", $S A K$, forthcoming, for more information and literature references.

${ }^{26}$ Unpublished; publication in preparation by F.-R. Herbin for the second volume of his catalogue Late Egyptian Religious Texts in the British Museum. It contains the Glorifications I, II, and III. For information about it, compare Assmann, Totenliturgien, III, 2008, p. 19; Kucharek, Totenliturgien, IV, 2010, p. 38; Backes, in Burkhard Backes et al. (eds.), Liturgical Texts, 2015, p. 20 (where it is mistakenly dated to $200 \mathrm{BCE}$ ). I would like to thank Ilona Regulski (the British Museum) for sending me photographs of this manuscript.

${ }^{27}$ For more information on this individual and his papyri, see Gill, “The funerary papyri of the brothers Djedher (TT 414) and Pakherkhonsu in the Museo Egizio and the British Museum with some observations on scribal practices", $S A K$, forthcoming.

${ }^{28}$ Published by Gill, Ritual Books, forthcoming. It contains the Spells against Enemies, the Interpretations of the Secrets of the Ritual of Driving Away the Aggressor, the Ritual of Felling Seth, the Second Book of Felling Seth, the Ritual for Bringing Sokar out of the Shrine, the Book of Protecting the Neshmet-Barque, the Great Ceremonies of Geb, and the Glorifications I.

${ }^{29}$ Published by Backes, Papyrus Schmitt, 2016. It contains the Great Ceremonies of Geb, the Glorifications I and II, the Introducing the Multitude on the Last Day of Tekh, and the Ritual for Bringing Sokar out of the Shrine.
${ }^{30}$ Unpublished. It is a Book of the Dead, extended with the Book of Protecting the Neshmet-Barque, the Ritual of Felling Seth, the Ritual of Driving Away the Aggressor, the Glorifications I, and the Ritual for Bringing Sokar out of the Shrine. Compare Assmann, Totenliturgien, III, 2008, p. 19; Backes, in Burkhard Backes et al. (eds.), Liturgical Texts, 2015, p. 21; Smith, Traversing Eternity, 2009, p. 168 with n. 6; Vuilleumier, Papyrus Princeton Pharaonic Roll 10, 2016, p. 147, for information on this papyrus.

${ }^{31}$ The papyrus contains the Book of Glorifying the Akh, the Spell of Breathing in the Netherworld, variants of Book of the Dead Spells 100 and 175, an unidentified excerpt from a litany, and Spells 1-4 of the Glorifications I. Compare the publications and studies of the various texts: Szczudlowska, ZÄS 98 (1970), pp. 50-80, with pls. 3-12; Szczudlowska, ZÄS 99 (1972), pp. 25-29; Herbin, SAK 32 (2004), pp. 171-204; Smith, Traversing Eternity, 2009, pp. 167-77; Wagner, in Burkhard Backes et al. (eds.), Liturgical Texts, 2015, pp. 179-202.

${ }^{32}$ Compare the publication by Burkard, Grabung im Asasif, III, 1986, pp. 38-41, with pls. 35-36, and Burkard, Spätzeitliche Osiris-Liturgien, 1995, pp. 13 and 111-29.

${ }^{33}$ Unpublished; the papyrus contains the so-called "chapitres supplémentaires" of the Book of the Dead and excerpts of the Glorifications I, the Lamentations, and the Glorifications IV. Compare Assmann, Totenliturgien, III, 2008, pp. 20-21; Backes, in Burkhard Backes et al. (eds.), Liturgical Texts, 2015, pp. 22 and 24; Kucharek, Totenliturgien, IV, 2010, p. 35; Kucharek, in Burkhard Backes et al. (eds.), Liturgical Texts, 2015, pp. 238-42 for information on this papyrus.

${ }^{34}$ Klakowicz, StudPap 19 (1980), pp. 9-38 and compare the pictures and the information on the database of the Book of the Dead project: Totenbuchprojekt Bonn, TM 129921, totenbuch.awk.nrw.de/objekt/tm129921 (last accessed on 15/06/2018). Re-publication in preparation by S. Vuilleumier; see Vuilleumier, in Ursula Verhoeven (ed.), Binsen-Weisheiten, 2015, pp. 341-67.

${ }^{35}$ Burkard, Grabung im Asasif, III, 1986, p. 38.

${ }^{36}$ Compare Smith, Traversing Eternity, 2009, p. 168 with n. 12 , and the literature referred to there. A full list of parallels, including those from the Pyramid Texts, is provided by Backes, Papyrus Schmitt, 2016, pp. 340-506; Assmann, Totenliturgien, III, 2008, pp. 37-41.

${ }^{37} \mathrm{Col} .1,1.1$; the beginning of that line is lost, so that it is not possible to reconstruct what originally came before $s 3 h w$, as the parallels simply have $s 3 h w$, "glorification".

${ }^{38} \mathrm{Col} .1,1.16$.

${ }^{39}$ Col. 1, 1l. 4 and 7; col. 2, 1l. 6 (h sp-2) and 11; col. 3, 1l. 1, 12 , and 13.

${ }^{40}$ Col. $1,1.14$ (hftj. $w=k h[s k]=f n=k$ tp. $w$ hrw $\left.\left.w . w . ..\right]\right) ;$ col. $2,1$. $8(h f t j . w=k), 1.9([s h r]=f h f t j . w=k), 1.13(s b j . w) ;$ col. 3, 1.6 (shr httj.w=k).

${ }^{41}$ Assmann, Totenliturgien, III, 2008, pp. 210-25.

${ }^{42}$ Compare Smith, Traversing Eternity, 2009, p. 167 with n. 4, for more information on this general feature 
in the Roman Period. For borders and guidelines in hieratic texts in general, see Tait, in Morris L. Bierbrier (ed.), Papyrus, 1986, pp. 75-76.

${ }^{43}$ See, for instance, the Books of the Dead in Taylor (ed.), Journey Through the Afterlife, 2010, p. 269 (fig. 81; Ptolemaic Period) and p. 283 (no. 151; 26th Dynasty).

${ }^{44}$ Compare Lucarelli, in John H. Taylor (ed.), Journey Through the Afterlife, 2010, p. 267. I am grateful to one of my anonymous reviewers for drawing my attention to this.

${ }^{45}$ There are two vaguely comparable examples; one in Möller, Paläographie, III, 1912, p. 35 (374; Leiden I 32) and one in Verhoeven, Buchschrift, 2001, p. 173 (P1; $\mathrm{Tb}$ pBM 10037, 2b,11), where in both cases a dot is added below the horizontal line.

${ }^{46}$ Assmann, Totenliturgien, III, 2008, p. 210. Compare Backes, Papyrus Schmitt, 2016, pp. 491-92, and Assmann, Totenliturgien, III, 2008, pp. 210-11 for further parallels, such as passages already attested in the Pyramid Texts.

${ }^{47}$ The lacuna is restored according to P. BM EA 10252 , col. 48, 1l. 2-3; P. BM EA 10317, col. 14, 1l. 1-2; P. Schmitt, col. 17, 11. 7-8.

${ }^{48}$ Reconstructed according to P. BM EA 10252, col. 48, 1. 4; P. BM EA 10317, col. 14, 1. 2; P. BM EA 10319, col. 11, 1. 28; P. Schmitt, col. 17, 1. 8.

${ }^{49}$ Compare the introduction above for more information on the presumable original length of the manuscript.

${ }^{50}$ See Szczudlowska, ZÄS 98 (1970), pl. III, and compare also Smith, Traversing Eternity, 2009, pp. 168 and 171, with n. 24.

${ }^{51}$ See Kucharek, in Burkhard Backes et al. (eds.), Liturgical Texts, 2015, p. 238.

${ }^{52}$ I would like to thank the anonymous reviewer for drawing my attention to this. For excerpts in papyri with Osiris liturgies in general, compare Kucharek, in Burkhard Backes et al. (eds.), Liturgical Texts, 2015, pp. 237-42.

${ }^{53}$ Assmann, Totenliturgien, III, 2008, p. 211. Compare Backes, Papyrus Schmitt, 2016, pp. 492-93 for further parallels, such as passages already attested in the Pyramid Texts.

${ }^{54}$ Reconstruction according to P. BM EA 10252, col. 48, 11. 4-5; P. BM EA 10317, col. 14, 1. 2; P. BM EA 10319, col. 25, 1. 28; P. Schmitt, col. 17, 1. 8.

${ }^{55}$ Due to the habit of writing h3y Wsjr hntj jmnt.t, the scribe confused the $j b$-sign with the jmn-sign.

${ }^{56}$ Restoration according to P. BM EA 10252, col. 48, 1. 6; P. BM 10317, col. 14, 1. 3; P. Schmitt, col. 17, 1. 9.

${ }^{57}$ For the translation Mendes instead of Busiris as, for instance, in Assmann, Totenliturgien, III, 2008, p. 211, see Backes, Papyrus Schmitt, 2016, pp. 492-93. Compare also Kucharek, Totenliturgien, IV, 2010, pp. 83-84 (reference courtesy of one of my anonymous reviewers). P. BM EA 10317, col. 14, 1. 3, however, has a clear writing for $D d w$ "Busiris".

${ }^{58}$ For Osiris and his connection to Sais, see Gill, Ritual Books, forthcoming, commentary of P. BM EA 10252, col. 25, 1.5 (The Great Ceremonies of Geb).

${ }^{59}$ LGG VI, 132b.

${ }^{60}$ Assmann, Totenliturgien, III, 2008, p. 211. Compare Backes, Papyrus Schmitt, 2016, pp. 494-95 for further parallels, such as passages already attested in the Pyramid Texts.

${ }^{61}$ Compare the following footnotes for more details.

${ }^{62}$ The relevant fragment is currently misplaced to the left, at the beginning of col. 2, 1l. 8-10.

${ }^{63}$ The relevant fragment is currently misplaced to the left, at the beginning of col. 2, 11. 8-10. The lacuna is restored according to P. BM EA 10252, col. 48, 1. 9; P. BM EA 10317, col. 14, 11. 5-6; P. Schmitt, col. 17, 1. 10.

${ }^{64}$ The lacuna is filled according to P. BM EA 10252 , col. 48, 1. 10; P. BM EA 10317, col. 14, 1. 6; P. Schmitt, col. 17, 1. 10.

${ }^{65}$ Restoration according to P. BM EA 10252, col. 48, 11. 10-11; P. BM EA 10317, col. 14, 1. 6; P. Schmitt, col. 17, 1l. 10-11.

${ }^{66}$ The lacunae are filled according to P. BM EA 10252 , col. 48, 1l. 12-13; P. BM EA 10317, col. 14, 11. 7-8; P. BM EA 10319, col. 11, 1. 34; P. Schmitt, col. 17, 11. 11-12.

${ }^{67}$ Assmann, Totenliturgien, III, 2008, p. 212.

${ }^{68}$ Restored according to P. BM EA 10252, col. 48, 1l. 14-15; P. Schmitt, col. 17, 1. 12. P. BM EA 10319, col. $11,1.35$ has $n h m=f-\underline{t} w$.

${ }^{69}$ Compare the hieratic writing of the ship-sign in col. 3 , 1. 3.

${ }^{70}$ Restoration according to P. BM EA 10252, col. 48, 1. 18; P. BM EA 10317, col. 14, 1. 11; P. BM EA 10319, col. 12, 1. 1; P. Schmitt, col. 17, 1. 13.

${ }^{71}$ I would like to thank the anonymous reviewer for this reading suggestion.

${ }^{72}$ P. Turin Cat. 1791, Spell 149, 1.48 (11th mound); compare the pictures on the database of the Totenbuchprojekt Bonn, TM 57201, totenbuch.awk.nrw. de/objekt/tm57201 (last accessed on 19/06/2018).

${ }^{73}$ Compare Gill, GM 246 (2015), pp. 38-40, and the literature references provided there. Add now also Backes, Papyrus Schmitt, 2016, pp. 495-98. The most recent study of the "address to the bringer of bas" is provided by Wüthrich and Stöhr, Ba-Bringer und Schattenabschneider, 2013.

${ }^{74}$ This hypocephalus belonged to Pawerem, the owner of the abovementioned P. BM EA 10252 and 10081. Compare the publication of this object by Gill, GM 246 (2015).

${ }^{75}$ Restored according to P. BM EA 10252, col. 48, 1. 20; P. BM EA 10317, col. 14, 1. 12; P. BM EA 10319, col. 12, 1. 2; P. Schmitt, col. 17, 1. 14. For further parallels, compare also the synopsis in Wüthrich and Stöhr, $B a$ Bringer und Schattenabschneider, 2013, pp. 54-55.

${ }^{76}$ The scribe forgot the two little strokes at the head of the bird for the writing of $($ compare the writing of that bird in the line above), so that he wrote the hieratic for $\sum_{\pi \in \text {. }}$.

${ }^{77}$ Compare Wüthrich and Stöhr, Ba-Bringer und Schattenabschneider, 2013, p. 29, with n. 2 for this translation.

${ }^{78}$ See Wb V, pp. 314-15, B, I. for $m t r$.

${ }^{79}$ Compare $W b$ I, p. 60, IV. for this meaning of $n j b=f$.

${ }^{80}$ P. BM EA 10317, col. 14, 1. 14; P. BM EA 10319, col. 12, 1. 4; P. Schmitt, col. 17, 1. 15. See Wüthrich and Stöhr, Ba-Bringer und Schattenabschneider, 2013, p. 29 and pp. 32-33. 
${ }^{81}$ P. BM EA 10317, col. 14, ll. 14-15; P. BM EA 10319, col. 12, 1. 5; P. Schmitt, col. 17, 11. 15-16. See Wüthrich and Stöhr, Ba-Bringer und Schattenabschneider, 2013, pp. 29 and 33, and Backes, Papyrus Schmitt, 2016, p. 497.

${ }^{82}$ Compare Wüthrich and Stöhr, Ba-Bringer und Schattenabschneider, 2013, p. 30 and pp. 34-35 for deviations in other versions.

${ }^{83}$ Assmann, Totenliturgien, III, 2008, p. 216. Compare Backes, Papyrus Schmitt, 2016, p. 498 and Assmann, Totenliturgien, III, 2008, pp. 216-18 for further parallels, such as passages already attested in the Pyramid Texts.

${ }^{84}$ For $s 3$ heing interchangeable with $s h$, see $W b$ IV, p. 24, 4. The parallels have $s$ s $h$; see, for instance, P. BM EA 10252, col. 49, 1. 1; P. BM EA 10317, col. 15, 1. 1; P. BM EA 10319, col. 12, 1. 9, or P. Schmitt, col. 17, 1. 18.

${ }^{85}$ Restored according to P. BM EA 10252, col. 49, 1. 2; P. BM EA 10317, col. 15, 1. 2; P. BM EA 10319, col. 12, 1. 11; P. Schmitt, col. 17, 1. 18.

${ }^{86}$ Compare the parallels: P. BM EA 10317, col. 15, 1. 2; P. BM EA 10319, col. 12, 1. 11; P. Schmitt, col. 17, 1. 19.

${ }^{87}$ Restored according to P. BM EA 10252, col. 49, 1. 3; P. BM EA 10317, col. 15, 1. 2; P. Schmitt, col. 17, 1. 19.

${ }^{88}$ The lacuna is filled according to P. BM EA 10252, col. 49, 1. 4; P. BM EA 10317, col. 15, 1l. 2-3; P. BM EA 10319, col. 12, 1. 12; P. Schmitt, col. 17, 1. 19.

${ }^{89}$ Restoration of the lacunae according to P. BM EA 10252, col. 49, 1l. 4-5; P. BM EA 10317, col. 15, 1. 3; P. BM EA 10319, col. 12, l. 12; P. Schmitt, col. 17, l. 19.

${ }^{90}$ The lacuna is filled according to P. BM EA 10252 , col. 49, 1. 6; P. BM EA 10317, col. 15, 1. 3; P. Schmitt, col. 17, 1. 20.

${ }^{91}$ The lacuna is filled according to P. BM EA 10252 , col. 49, 1l. 6-7; P. BM EA 10317, col. 15, 1. 4; P. BM EA 10319, col. 12, 1. 13; P. Schmitt, col. 17, 1. 20.

${ }^{92}$ P. BM EA 10317, col. 15, 1. 2; P. Schmitt, col. 17, 1. 19; P. BM EA 10319, col. 12, 11. 11-12 have clearly $\underline{D} d w$ "Busiris" written.

${ }^{93}$ Assmann, Totenliturgien, III, 2008, pp. 216-17.

${ }^{94}$ No clear traces of $m 3^{c}-h r w$ are preserved; neither at the end of 1.11 nor the beginning of 1.12 .

${ }^{95}$ Restored according to P. BM EA 10252, col. 49, 1. 8; P. BM EA 10317, col. 15, 1. 5; P. BM EA 10319, col. 12, 1. 14; P. Schmitt, col. 17, 1. 21.

${ }^{96}$ Reconstruction according to P. BM EA 10252, col. 49, 1. 10; P. BM EA 10317, col. 15, 1. 6; P. BM EA 10319, col. 12, 1. 15; P. Schmitt, col. 17, 1. 21.

${ }^{97}$ None of the parallels has something between $n=k$ and tk3; compare, for instance, P. BM EA 10252, col. 49, 1l. 10-11; P. BM EA 10317, col. 15, 1. 6, or P. Schmitt, col. 17, 1. 22. The traces of ink still preserved, however, suggest this restoration for our version.

${ }^{98}$ See Kurth, Einführung ins Ptolemäische, I, 2007, p. 127 (4.) for the value $h j$ of this sign.

${ }^{99}$ Assmann, Totenliturgien, III, 2008, pp. 219-20.

${ }^{100}$ Assmann, Totenliturgien, III, 2008, p. 219 reads $n b . t$ jmn.t, "Herrin des Westens". However, the sign written in P. BM EA 10252, col. 50, 1. 14; P. BM EA 10319, col. 13, 1. 1; P. Schmitt, col. 17, 1. 34 is clearly ' $n h$ and not the divine/west standard.

${ }^{101}$ The lacuna is filled according to P. BM EA 10252 , col. 50, 1. 14; P. BM EA 10317, col. 16, 1. 11; P. BM EA 10319, col. 12, 1. 36-col. 13, 1. 1; P. Schmitt, col. 17, 1. 34 .

${ }^{102}$ See P. BM EA 10252, col. 50, 1. 15; P. BM EA 10319 , col. 13, 1. 2; P. Schmitt, col. 17, 1. 34.

${ }^{103}$ Restoration according to P. BM EA 10252, col. 50, 1. 16; P. BM EA 10317, col. 16, 1. 12; P. BM EA 10319, col. 13, 1. 2; P. Schmitt, col. 17, 11. 34-35.

${ }^{104}$ Emendation based on the parallels; see, for instance, P. BM EA 10252, col. 50, 1. 16; P. BM EA 10317, col. 16, l. 12; P. BM EA 10319, col. 13, 1. 2; P. Schmitt, col. 17, 1. 35.

${ }^{105}$ Compare, for instance, P. BM EA 10252, col. 50, 11. 9-10; P. BM EA 10317, col. 16, 11. 8-9; P. BM EA 10319, col. 12, 1. 34; P. Schmitt, col. 17, 1l. 32-33.

${ }^{106}$ Assmann, Totenliturgien, III, 2008, p. 220.

${ }^{107}$ Compare P. Schmitt, col. 17, 1l. 36-37; P. BM EA 10319, col. 13, 11. 7-8; P. BM EA 10317, col. 16, 11. 16-17. The version of P. BM EA 10252, col. 50, 11. 22-23 is only fragmentarily preserved.

${ }^{108}$ Backes, Papyrus Schmitt, 2016, p. 333, and Smith, Traversing Eternity, 2009, p. 11. The relevant invocation from P. Turin Cat. 2117 (R 08) that counts into that category is written in bold.

${ }^{109}$ Smith, Traversing Eternity, 2009, p. 169.

${ }^{110}$ See Backes, in Burkhard Backes et al. (eds.), Liturgical Texts, 2015, p. 24, and compare his list of ritual papyri on pp. 18-23.

${ }^{111}$ Compare Gill, Ritual Books, forthcoming, chapter 7.

\section{Bibliography}

Assmann, J., Altägyptische Totenliturgien, III. Osirisliturgien in Papyri der Spätzeit, Heidelberg 2008.

Assmann, J., “Egyptian Mortuary Liturgies”, in: S. Israelit-Groll (ed.), Studies in Egyptology, Presented to Miriam Lichtheim, I, Jerusalem 1990, pp. 1-45.

Backes, B., Der „Papyrus Schmitt“(Berlin P. 3057): ein funeräres Ritualbuch der ägyptischen Spätzeit (Ägyptische und Orientalische Papyri und Handschriften des Ägyptischen Museums und Papyrussammlung Berlin 4), I-II, Berlin and Boston 2016.

Backes, B., "Gedanken zu Kategorien und Funktionspotentialen funerärer Ritualpapyri”, in: B. Backes and J. Dieleman (eds.), Liturgical Texts for Osiris and the Deceased in Late Period and Greco-Roman Egypt. Liturgische Texte für Osiris und Verstorbene im spätzeitlichen Ägypten, Proceedings of the colloquiums at New York (ISAW), 6 May 2011, and Freudenstadt, 18-21 July 2012 (Studien zur spätägyptischen Religion 14), Wiesbaden 2015, pp. 15-35.

Burkard, G., Grabung im Asasif 1963-1970, III. Die Papyrusfunde (AV 22), Wiesbaden 1986.

Burkard, G., Spätzeitliche Osiris-Liturgien im Corpus der Asasif-Papyri (ÄAT 31), Wiesbaden 1995.

Clarysse, W., "Notes de prosopographie thébaine, 6. Une famille de pastophores thébains”, CdE 53 (1978), pp. 239-43.

Depauw, M., The Archive of Teos and Thabis from Early Ptolemaic Thebes: P. Brux. Dem. Inv. E. 8252-8256 (MRE 8), Bruxelles 2000.

Erman, A. and H. Grapow (eds.), Wörterbuch der ägyptischen Sprache, I-VII, Leipzig and Berlin 1926-1963.

Fabretti, A., F. Rossi e R.V. Lanzone, Regio Museo di Torino. 
Antichità Egizie (Catalogo generale dei musei di antichità e degli oggetti d'arte raccolti nelle gallerie e biblioteche del regno. Serie prima Piemonte, 1), Torino 1882.

Gill, A.-K., The Hieratic Ritual Books of Pawerem (P. BM EA 10252 and P. BM EA 10081) from the Late 4th Century $B C$ (Studien zur spätägyptischen Religion), forthcoming.

Gill, A.-K., "The Unusual Hypocephalus of Pawerem, Son of Qaqa (Stockholm MME 1977:6)", GM 246 (2015), pp. 37-48.

Herbin, F.-R., “Un texte de glorification”, SAK 32 (2004), pp. 171-204.

Jelínková-Reymond, E., "Recherches sur le rôle des " gardiens des portes » (iry-^3) dans l'administration générale des temples égyptiens", CdE 28 (1953), pp. 39-59.

Johnson, J.H. (ed.), The Demotic Dictionary of the Oriental Institute of the University of Chicago, Chicago 2011.

Klakowicz, B.E., “The Funerary Papyrus of 'Thd (P. Palau Rib. inv. 68)", StudPap 19 (1980), pp. 9-38.

Kucharek, A., Altägyptische Totenliturgien, IV. Die Klagelieder von Isis und Nephthys in Texten der Griechisch-Römischen Zeit, Heidelberg 2010.

Kucharek, A., "Vignetten und Exzerpte in Osirisliturgien", in: B. Backes and J. Dieleman (eds.), Liturgical Texts for Osiris and the Deceased in Late Period and Greco-Roman Egypt. Liturgische Texte für Osiris und Verstorbene im spätzeitlichen Ägypten: Proceedings of the Colloquiums at New York (ISAW), 6 May 2011, and Freudenstadt, 18-21 July 2012 (Studien zur spätägyptischen Religion 14), Wiesbaden 2015, pp. 233-42.

Kurth, D., Einführung ins Ptolemäische. Eine Grammatik mit Zeichenliste und Übungsstücken, I-II, Hützel 2007-2008.

Leahy, A., "Two Late Period Stelae in the Fitzwilliam Museum", SAK 8 (1980), pp. 169-80.

Leitz, C. (ed.), Lexikon der ägyptischen Götter und Götterbezeichnungen, I-VIII (OLA 110-116), Leuven 20022003.

Lucarelli, R., "Making the Book of the Dead”, in: J.H. Taylor (ed.), Journey Through the Afterlife: Ancient Egyptian Book of the Dead, London 2010, pp. 264-73.

Lüddeckens, E., Demotisches Namenbuch, Wiesbaden 1980-2000.

Möller, G., Hieratische Paläographie. Die ägyptische Buchschrift in ihrer Entwicklung von der fünften Dynastie bis zur römischen Kaiserzeit, I-III, Leipzig 1909-1912.

Ramond, P., "Un socle pour une statuette de Thot (Collection Pierre Ramond No. 70-146)”, JEA 65 (1979), pp. 169-71.

PN = Ranke, H., Die ägyptischen Personennamen, I-III,
Glückstadt 1935-1977.

Smith, M., Traversing Eternity. Texts for the Afterlife from Ptolemaic and Roman Egypt, Oxford 2009.

Szczudlowska, A., "Liturgical Text Preserved on Sȩkowski Papyrus”, ZÄS 98 (1970), pp. 50-80.

Szczudlowska, A., "Pyramid Texts Preserved on Sȩkowski Papyrus”, ZÄS 99 (1972), pp. 25-29.

Tait, W.J., "Guidelines and Borders in Demotic Papyri", in: M.L. Bierbrier (ed.), Papyrus. Structure and Usage (British Museum Occasional Paper 60), London 1986, pp. 63-89.

Taylor, J.H. (ed.), Journey Through the Afterlife. Ancient Egyptian Book of the Dead, London 2010.

Verhoeven, U., Untersuchungen zur späthieratischen Buchschrift (OLA 99), Leuven 2001.

Vuilleumier, S., "Un même propriétaire pour deux manuscrits? Paléographie du Papyrus Barcelone Palau-Rib. inv. 80”, in: U. Verhoeven (ed.), Ägyptologische „Binsen"-Weisheiten I-II. Neue Forschungen und Methoden der Hieratistik, Akten zweier Tagungen in Mainz im April 2011 und März 2013, Mainz 2015, pp. 341-67.

Vuilleumier, S., Un ritual osirien en faveur de particuliers à l'époque ptolémaïque: Papyrus Princeton Pharaonic Roll 10 (Studien zur spätägyptischen Religion 15), Wiesbaden 2016.

Wagner, M., "Das Buch zur Verklärung des Ach”, in: B. Backes and J. Dieleman (eds.), Liturgical Texts for Osiris and the Deceased in Late Period and Greco-Roman Egypt. Liturgische Texte für Osiris und Verstorbene im spätzeitlichen Ägypten, Proceedings of the Colloquiums at New York (ISAW), 6 May 2011, and Freudenstadt, 18-21 July 2012 (Studien zur spätägyptischen Religion 14), Wiesbaden 2015, pp. 179-202.

Wüthrich, A. and S. Stöhr, Ba-Bringer und Schattenabschneider: Untersuchungen zum so genannten Totenbuchkapitel 191 auf Totenbuchpapyri (SAT 18), Wiesbaden 2013.

Zauzich, K.-T., Die ägyptische Schreibertradition in Aufbau: Sprache und Schrift der demotischen Kaufverträge aus ptolemäischer Zeit (̈̈A 19), I-II, Wiesbaden 1968.

\section{Online sources}

Das altägyptische Totenbuch. Ein digitales Textzeugenarchiv, http://totenbuch.awk.nrw.de.

Institute Français d'Archéologie Orientale - Le Caire, Conseil Suprême des Antiquités, Cachette de Karnak, http://www.ifao.egnet.net/bases/cachette/.

Museo Egizio. Collezione, https://collezioni.museoegizio.it.

Trismegistos. An Interdisciplinary Portal of Papyrological and Epigraphical Resources, https://www.trismegistos. org. 


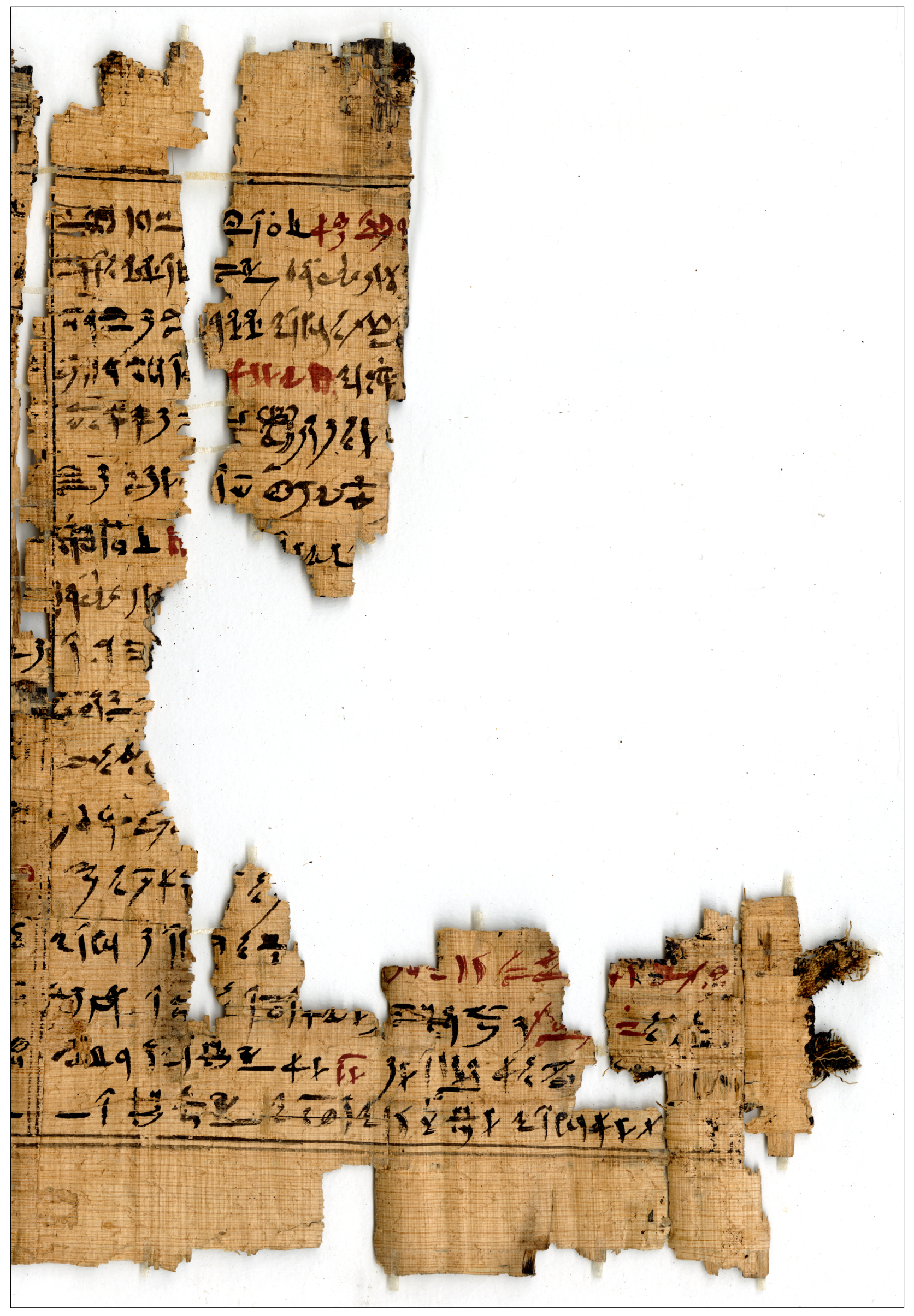




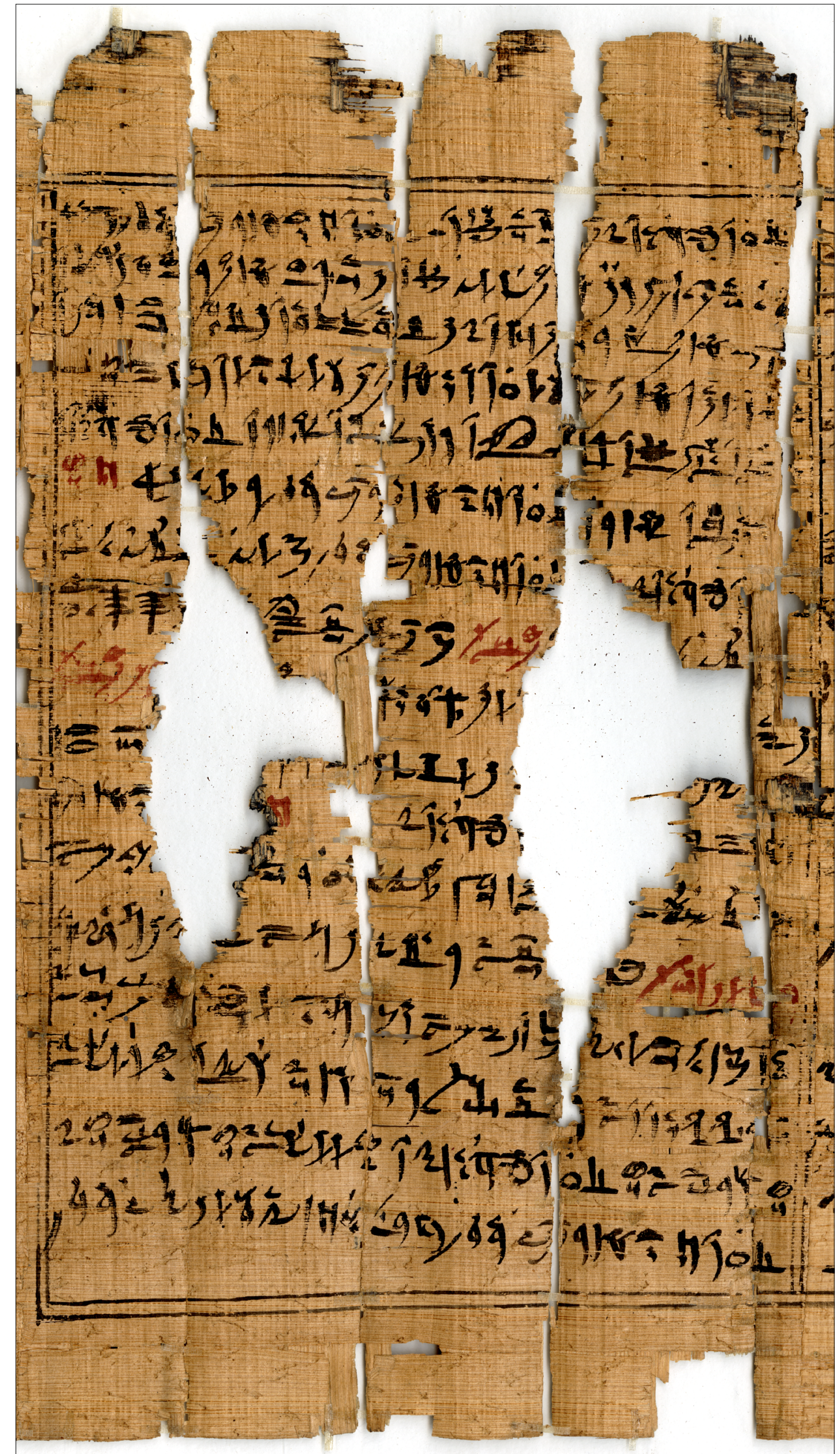

PI. 2: P. Turin Cat. 2117 (R 08), recto, col. 2. Scan by Museo Egizio. 


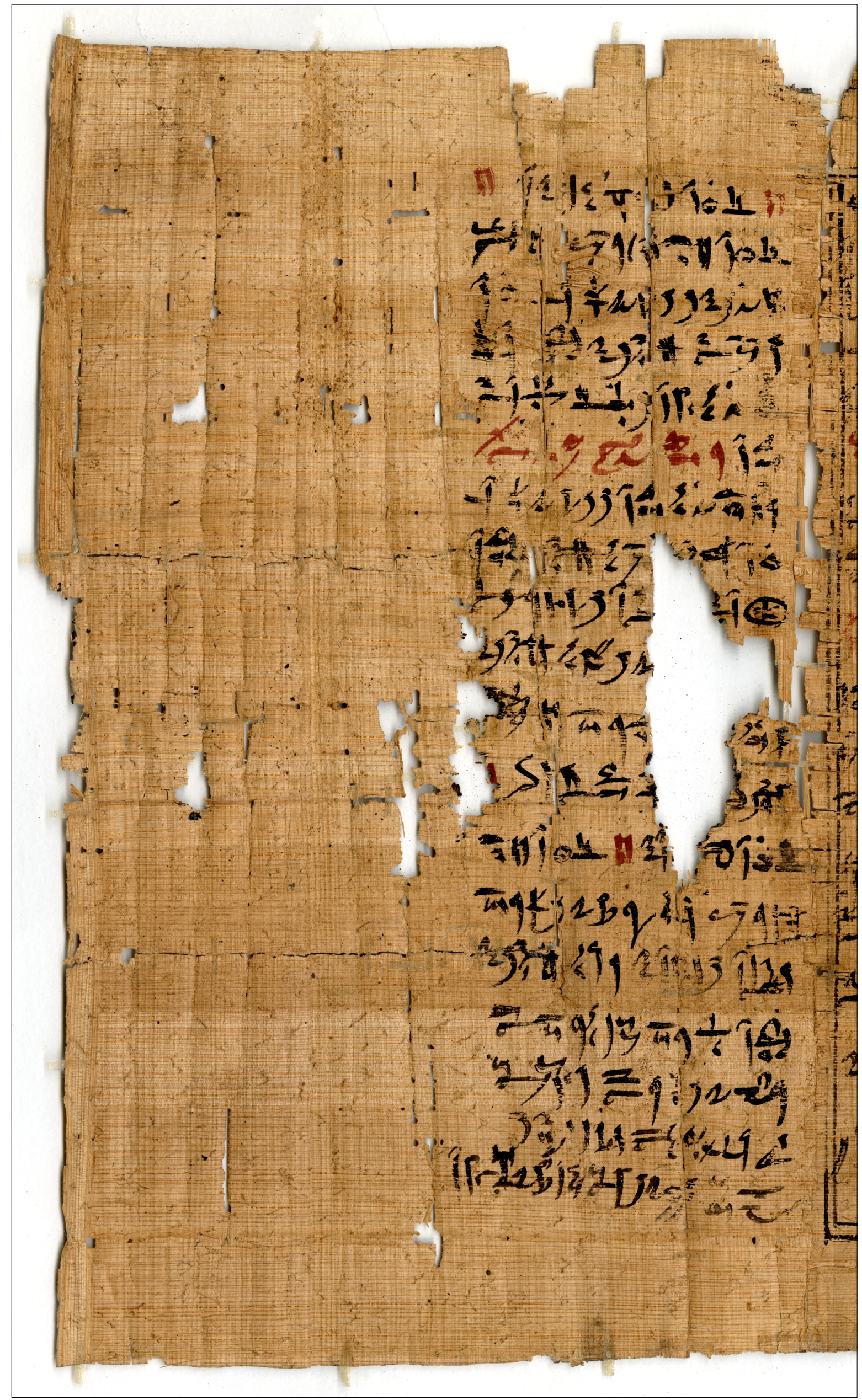

PI. 3: P. Turin Cat. 2117 (R 08), recto, col. 3. Scan by Museo Egizio. 